\title{
Practitioner's review: medication for children and adolescents with autism spectrum disorder (ASD) and comorbid conditions
}

\author{
Christian Popow (D) S Susanne Ohmann · Paul Plener
}

Received: 12 January 2021 / Accepted: 15 May 2021 / Published online: 23 June 2021

(C) The Author(s) 2021

\begin{abstract}
Alleviating the multiple problems of children with autism spectrum disorder (ASD) and its comorbid conditions presents major challenges for the affected children, parents, and therapists. Because of a complex psychopathology, structured therapy and parent training are not always sufficient, especially for those patients with intellectual disability (ID) and multiple comorbidities. Moreover, structured therapy is not available for a large number of patients, and pharmacological support is often needed, especially in those children with additional attention deficit/ hyperactivity and oppositional defiant, conduct, and sleep disorders.
\end{abstract}

Keywords Autism spectrum disorder - ADHD · Children and adolescents · Pharmacotherapy

Practitioner Review: Medikamentöse Behandlung von Kindern und Jugendlichen mit Autismus-Spektrum-Störung (ASS) und Komorbiditäten

Zusammenfassung Die Linderung der vielfältigen Probleme von Kindern mit Autismus-Spektrum-Störung (ASS) und ihrer Begleiterkrankungen stellt für die betroffenen Kinder, Eltern und Therapeuten eine große Herausforderung dar. Aufgrund einer komplexen Psychopathologie reichen strukturierte Therapie

C. Popow $(\bowtie) \cdot$ S. Ohmann $\cdot$ P. Plener

Dept. Child and Adolescent Psychiatry, Medical University of Vienna, Waehringer Guertel 18-20, 1090 Vienna, Austria christian.popow@meduniwien.ac.at

S. Ohmann

susanne.ohmann@meduniwien.ac.at

P. Plener

paul.plener@meduniwien.ac.at und Elterntraining nicht immer aus, insbesondere bei Menschen mit geistiger Behinderung (GB) und multiplen Komorbiditäten. Darüber hinaus steht für viele Patienten keine strukturierte Therapie zur Verfügung, und häufig ist pharmakologische Unterstützung erforderlich, insbesondere bei Kindern, bei denen eine Aufmerksamkeitsdefizit-/Hyperaktivitätsstörung und oppositionelle Trotz-, Verhaltens- oder Schlafstörungen hinzukommen.

Schlüsselwörter Autismus-Spektrum-Störung · ADHS · Kinder und Jugendliche · Pharmakotherapie

\section{Introduction}

Autism spectrum disorder (ASD) is a common [73], complex, genetically based, disabling disorder [15] that needs specific knowledge and parenting skills [165] and burdensome, costly treatment. The complex clinical picture is characterized in ICD-11 6A02 [320] by

- Persistent deficits in the ability to initiate and sustain reciprocal social interaction and social communication,

- A range of restricted, repetitive, and inflexible patterns of behavior and interests, and

- A high prevalence of intellectual disability, language impairments, and other comorbid disorders

and a number of comorbid conditions such as attention deficit/hyperactivity disorder (ADHD), sleep disorders, convulsions, oppositional defiant disorder (ODD), anxieties, obsessions and compulsions (OCD), depression, and numerous other symptoms and conditions that are discussed as to whether they represent "core" or comorbid problems [281]. These conditions differ in symptomatology, prevalence, and treatability from those of normally developing children. These 
Table 1 Abbreviations

\begin{tabular}{|c|c|c|c|}
\hline Abbrev. & Definition & Abbrev. & Definition \\
\hline ABA & Applied behavioral analysis & IQ & Intelligence (Quotient) \\
\hline ACTH & Adrenocorticotropic hormone, corticotropin & LGS & Lennox-Gastaut syndrome \\
\hline$A D$ & Antidepressant & LKS & Landau-Kleffner syndrome \\
\hline$A D$ & & MAOI & Monoamino oxidase inhibitor \\
\hline ADHD & Attention deficit/hyperactivity syndrome & MPEP & 2-methyl-6- (phenylethynyl)pyridine \\
\hline BD & Bipolar disorder & MT1 & Melatonin 1 (receptor) \\
\hline ASD & Autism spectrum disorder & NDRI & Norepinephrine-dopamine reuptake inhibitor \\
\hline BPD & Borderline personality disorder & NMDA & $\mathrm{N}$-methyl-D-aspartate \\
\hline CBT & Cognitive behavioral therapy & OCD & Obsessive compulsive disorder \\
\hline CSWS & Continuous spike waves during slow-wave sleep & ODD/CD & Oppositional defiant disorder/conduct disorder \\
\hline DSM-5 & $\begin{array}{l}\text { Diagnostic and Statistic Manual for Mental Disorders, } \\
\text { 5th edition }\end{array}$ & $\mathrm{PE}$ & Partial epilepsy \\
\hline DRESS & Drug rash with eosinophilia and systemic symptoms & PECS & Picture exchange communication system \\
\hline EF & Executive functions (functioning) & REM sleep & Rapid eye movement sleep \\
\hline ESES & Electrical status epilepticus during slow-wave sleep & RLS & Restless legs syndrome \\
\hline FDA & Food and Drug Administration & SGA & Second generation antipsychotic \\
\hline FGA & First generation antipsychotic & SSRI & Selective serotonin reuptake inhibitor \\
\hline FXS & Fragile $X$ syndrome & SNRI & Selective serotonin and norepinephrine reuptake inhibitor \\
\hline GABA & Gamma-amino-butyric acid & SE & Side effects \\
\hline GAD & Generalized anxiety disorder & $t 1 / 2$ & Half life \\
\hline СBT & Cognitive behavioral therapy & TCA & Tricyclic antidepressant \\
\hline ICD & International Classification of Diseases & TCM & Traditional Chinese medicine \\
\hline ID & Intellectual disability & TEACCH & $\begin{array}{l}\text { Treatment and education of autistic and related communication handi- } \\
\text { capped children }\end{array}$ \\
\hline IGF-1 & Insulin-like growth factor - 1 & VPS & Valproic acid \\
\hline
\end{tabular}

differences, partly related to the reduced flexibility (for change), partly to genetic and social conditions, may render therapy and its prognosis difficult, and will increase the impairments of self-worth/self-efficacy and the tendency for depression in the children on the spectrum. Comorbid conditions also seem to contribute to the increased mortality of children with ASD [304].

ASD comprises persons with a very low functional level up to a normal or even supranormal level with relatively low impairment. The disorder may not be cured but largely ameliorated by therapy and guided intrafamilial support [36, 165]. Especially in children with a low functional level, structured behavioral therapies [178] such as $\mathrm{ABA}^{1}$ and its variants, $\mathrm{TEACCH}^{2}$ or $\mathrm{PECS}^{3}$ have been proven to be beneficial. Therapeutic success will depend on the level of impairment, the intrafamilial and peer relation support, the availability, quality and quantity of therapeutic support [183, 192], the age at diagnosis $[86,119,229,263,299]$, the types and number of comorbid conditions, and the financial support provided by the state or the social insurance, because an individual family will usually not dispose

\footnotetext{
1 applied behavioral analysis [209].

2 Treatment and Education of Autistic and related Communication Handicapped Children [211].

3 Picture Exchange Communication System [89].
}

of the necessary means. Less affected children will present with flexibility problems and may easily be overburdened with social problems [166]. Additional challenges may be caused by comorbid conditions like ADHD, dysexecutive problems, depression, anxiety disorders, or seizures $[10,18,24,38,105,106,187$, 201, 281] (Table 2 [187, 223, 281]). Therapy should aim at attaining autonomy, flexibility, social competence, an educational level that is appropriate to the individual intellectual capacity of the child, and provide the basis for a self-determined and socially integrated life.

"Conventional" pharmacotherapy is targeted to reduce inappropriate behavior and the associated burden for family, school, and the social environment, to limit inattention, impulsivity, and hyperactivity associated with $\mathrm{ADHD}$, and to reduce the risk of seizures. Up to two-thirds of children with ASD are treated with psychotropics, and a third with multiple drugs [92, 156, 288]. Newer trends aim at improving social communication [21] or at transferring experimental therapies into real life [81, 171]. Examples include improving the imbalance between excitatory (glutamatergic) and inhibitory (GABA-ergic) neurotransmission [180, 216] or synaptic plasticity [34]. Among the most promising candidate substances are [171], NMDA ${ }^{4}$ antagonists [33], memantine [139], and

\footnotetext{
4 N-methyl-D-aspartate.
} 
Table 2 ASD: relevant comorbid disorders

\begin{tabular}{|l|l|l|l|}
\hline Disorders & $\begin{array}{l}\text { Normotypic Chil- } \\
\text { dren \% }\end{array}$ & $\begin{array}{l}\text { ASD Chil- } \\
\text { dren \% }\end{array}$ & References \\
\hline Anxiety disorders & $20-40$ & $11-84$ & {$[281]$} \\
\hline Sensory integration/EF & $7.5-15$ & $>75$ & {$[126,198]$} \\
\hline Sleep disorder & $22-32$ & $40-80$ & {$[175]$} \\
\hline ADHD & $5-7$ & $30-75$ & {$[10,58,266]$} \\
\hline ODD/CD & & $30-90$ & {$[264]$} \\
\hline Intellectual disability & $2-3$ & $25-70$ & {$[163]$} \\
\hline OCD & 2.5 & $8-37$ & {$[187]$} \\
\hline Epilepsy & $1-3$ & $20-34$ & {$[24,105,261]$} \\
\hline Depression/BPD & $2-3$ & $11-20$ & {$[161,201]$} \\
\hline Tic disorder & $1-2$ & $9-20$ & {$[260]$} \\
\hline $\begin{array}{l}\text { Central auditory processing } \\
\text { disorder }\end{array}$ & $2-5$ & $?$ & {$[16]$} \\
& & & \\
\hline
\end{tabular}

d-Cycloserine [68, 214], the GABA agonists, baclofen or arbaclofen [77, 130], oxytocin [17, 21, 47, 113, 313], vasopressin [235] or balovaptan [27], and insulin-like growth factors (IGF-I) [44, 301]. Among these, only the binding hormone oxytocin has gained widespread attention, stimulating a considerable number of clinical studies, although with inconsistent results [228].

In order to improve the multiple medical, social, behavioral, learning, or sleep-related problems, a number of drugs have been recommended and studied in clinical trials [241]. In addition, a number of experimental therapies, such as diets and brain extracts, were tried, most of them without any clinical evidence. Because the individual reaction to pharmacotherapy varies considerably [28], individualized treatment is mandatory [218]. We, therefore, performed a systematic review of the current literature, aiming at providing an overview on recommended pharmacotherapy for ASD and its most important comorbid disorders. The review is divided into three sections:

1. Pharmacologic agents

2. Therapy for common problems of ASD and comorbid disorders

3. Other substances, supplementary and alternative therapies.

\section{Methods}

We searched the database PubMed/Medline for the following terms: autism AND pharmacotherapy OR medication, and retrieved 4.248 citations. Restricting the period covered to the years 2000-2019 and the language to English OR French OR German; 3.607 citations remained, including 1120 reviews. Selecting relevant titles, primarily taking into account the contents and quality of the papers, and secondarily the authors, publication media (impact factor), and date (selecting newer references), 223 remained. These were carefully studied in detail and supplemented by 742 additional relevant articles retrieved by specific topic searches that were considered important for under- standing during the writing process. This added to 965 references of which 325 were cited in this article, depending on their subjectively estimated significance ${ }^{5}$, and aiming at not overloading the chapter with citations (see Fig. 1). The relationship between reviews and meta-analyses and original papers in the cited references was $1: 3$.

\section{Pharmacotherapy of ASD}

In the following, we will discuss the various groups of pharmaceuticals used in children and adolescents with ASD, namely antipsychotics, antidepressants, and anticonvulsants.

\section{Antipsychotics}

Antipsychotics influence dopamine neurotransmission, act sedating in lower, antipsychotic in medium, and narcotic in high doses. First generation antipsychotics (FGA), especially haloperidol, have been shown to influence stereotypic and hyperactive behavior, to reduce temper tantrums and social isolation [9]. FGAs should no longer be used because of an inappropriate risk-benefit ratio related to cognitive as well as early and late (e.g., dyskinetic) side effects. As an alternative, second generation antipsychotics (SGAs), especially risperidone, aripiprazole, and quetiapine, are substances of choice for treating aggression, self-injuring behavior, temper tantrums, withdrawal, tics, and rituals.

This is also true for the SGA clozapine because of its dangerous hematologic side effects [152]. As an alternative, SGAs, especially risperidone, aripiprazole, and quetiapine, are substances of choice for treating aggression, self injuring behavior, temper tantrums, withdrawal, tics and rituals $[35,43,62,68,103,122$, 153, 170, 221, 231, 241, 249, 262, 272, 290, 295, 319]. Other SGAs (such as asenapine and iloperidone) may also be used off-label but do not offer advantages [326]. Positive effects should be balanced against (metabolic, endocrine, neurologic, and cardiac) side effects [61, 273]. Therefore, mainly low-dose application should be tried. Recommended dosages and specific features are listed in Table 4. Adding topiramate to risperidone therapy was more effective on overall behavior when compared to risperidone monotherapy [257]. A potential adverse effect of topiramate on language development [227] has, nevertheless, to be considered.

\section{Antidepressants}

In normally developing children, selective serotonin antagonists (SSRIs) are effective against depressive

\footnotetext{
5 Again, selecting more carefully performed studies, more recent, often cited papers, and preferring reviews, if available, over original studies.
} 
Fig. 1 Processing of records

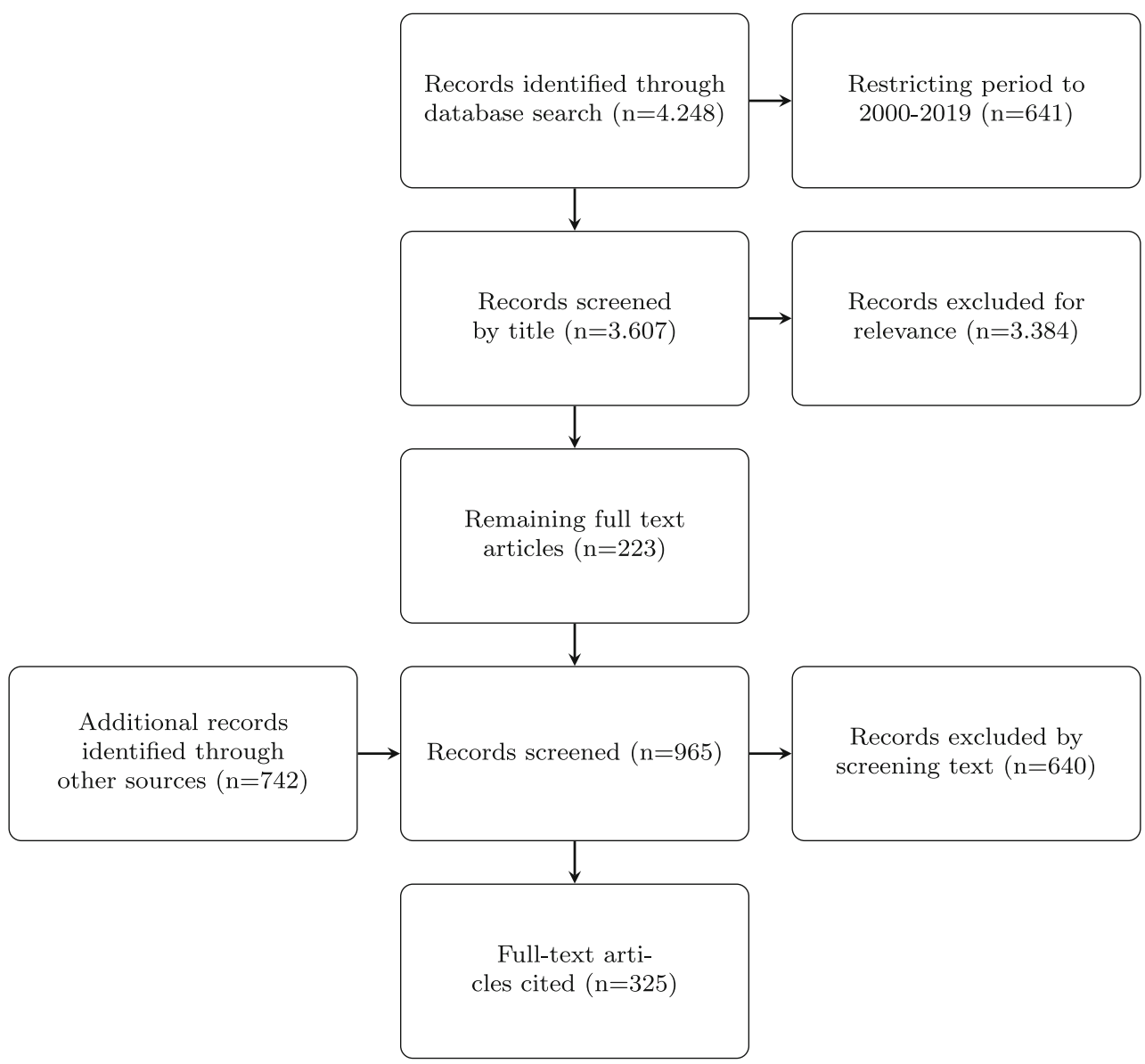

symptoms with substance-related differences in effectivity and side effects. SSRIs also act against anxiety disorders in lower dosages and against OCD in higher dosages, compared to the treatment of depression. In children with ASD, SSRIs are widely prescribed, but their therapeutic effect is less evident [319]. Other $\mathrm{AD}$ agents, such as MAOIs, mirtazapine, hypericum, etc., also seem to produce only little effect, possibly because of elevated peripheral serotonin blood levels in a number of children and adolescents with ASD [100, 232, 309, 319].

A few studies suggest improvements of repetitive and stereotypic behavior with $\mathrm{AD}$ therapy in children with ASD [221], although this was not reported by King et al. [168] or Williams et al. [319]. Side effects of SSRIs usually are mild but may be exaggerated in children with ASD, especially when children are restless and agitated [173]. Bupropion, a NDRI ${ }^{6}$ acts like a stimulant, may create dependence, and should not be used in adolescents. Mirtazapine [243], a tricyclic $\mathrm{AD}$, has modest antidepressant effects and further acts as a sedative and hypnotic agent by stimulating $\mathrm{H} 1$ receptors but is slowly eliminated $(t 1 / 2$ $37 \mathrm{~h})$, strongly increases appetite, and leads to sig-

${ }^{6}$ norepinephrine and dopamine reuptake inhibitor. nificant weight gain [143]. Studies in autistic children are scarce (e.g., [243]), and long-term studies are not available. Mirtazapine, therefore, should not be used or only used for a limited period and in low doses. Clomipramine and tricyclic antidepressants should only be used with care because of their severe side effects, and duloxetine and pregabaline have not been systematically studied in children and adolescents with ASD.

In summary, although $\mathrm{AD}$ medication, especially SSRIs, is widely prescribed in children and adolescents, its effectiveness is limited to not evident in children with ASD, and side effects may be more exaggerated in these patients. Therefore, the use of ADs in ASD can generally not be recommended. Because of their widespread use, pharmacologic data on $\mathrm{AD}$ medication are nevertheless summarized in Table 5.

\section{Anticonvulsants}

Anticonvulsants may be used to treat epilepsies, bipolar disorders, and externalizing behavioral problems? Anticonvulsant treatment of children with ASD [83, 133,261 , like in other patients with convulsions, de-

\footnotetext{
7 With inconsistent results [129, 137].
} 
Table 3 ASD Symptoms, comorbid disorders and (off-label) pharmacotherapy

\begin{tabular}{|c|c|}
\hline Symptoms & Available drugs \\
\hline $\begin{array}{l}\text { Behavioral problems, restlessness, tem- } \\
\text { per tantrums, self-injuring behavior }\end{array}$ & Antipsychotics, (anticonvulsants) \\
\hline Social problems & $\begin{array}{l}\text { Oxytocin, D-cycloserin, meman- } \\
\text { tine (experimental) }\end{array}$ \\
\hline Sleeping problems & $\begin{array}{l}\text { Melatonin, antipsychotics, anti- } \\
\text { histaminics }\end{array}$ \\
\hline ADHD & $\begin{array}{l}\text { Atomoxetin, methylphenidate, } \\
\text { amphetamines, (guanfacine ER) }\end{array}$ \\
\hline Tics & $\begin{array}{l}\text { Antipsychotics, }\left(\alpha_{2} \text { sympath- }\right. \\
\text { omimetics, SSRIs) }\end{array}$ \\
\hline Depression & SSRIs, SNRIs, (+ antipsychotics) \\
\hline Bipolar disorder & Antipsychotics, (lithium) \\
\hline Anxiety \& OCD & $\begin{array}{l}\text { SSRIs (higher dosage needed), } \\
\text { pregabaline }\end{array}$ \\
\hline Seizures & $\begin{array}{l}\text { Valproic acid, levetiracetam, } \\
\text { lamotrigine (and others) }\end{array}$ \\
\hline Psychosis & Antipsychotics \\
\hline GI problems & Diet? probiotics? \\
\hline
\end{tabular}

pends on the type of convulsions and should always be combined with psychosocial support [261].

The most commonly used pharmacotherapeutics are valproic acid, lamotrigine, levetiracetam, and ethosuximide [96], cf. Table 6. In select syndromes such as Landau-Kleffner syndrome or ESES ${ }^{8}$, corticosteroids, ACTH, or immunoglobulin therapy may be considered [303]. Additional nonpharmacological therapeutic options for therapy-resistant epilepsies include vagus nerve stimulation [184], ketogenic diet, and neurosurgical interventions [114]. It is not clear whether an interictal epileptiform EEG may be a cofactor contributing to neurologic deterioration or progressing developmental retardation [310]. Pharmacologic treatment should always be considered if symptoms get worse.

\section{Therapy for Common Problems of ASD and Comorbid Disorders}

Pharmacotherapy for patients with ASD aims at reducing inappropriate behavior and the related intrafamiliar and psychological stress, at improving engagement in therapy, health-related quality of life, performance at school and work, social integration and participation, and at treating comorbid problems such as ADHD or seizures $[14,53,67,72,154,156,164$, $180,210,220,245,274]$. Limitations include inconsistent evidence of efficiency and side effects, especially with long-term use [107]. A recent study [53] compared the benefits and adverse effects of the pharmacological treatment of a number of targeted symptoms in 505 children with ASD. The authors found small to medium benefits to adverse effects ratios and

${ }^{8}$ Electrical status epilepticus during slow-wave sleep. concluded that individualized treatment is mandatory. Table 3 summarizes the medical indications and available drugs.

\section{ADHD}

ASD and ADHD share genetic, neurophysiological, and clinical similarities $[10,181]$. Both disorders affect attention, flexibility, planning, and response inhibition, have a high heritability, early onset, overlapping comorbidities, and prevail in males [50,58]. Hans Asperger already described attention problems as "almost regularly occurring in children of this type" [13]. Ronald et al. [265] found significant correlations between ASD and ADHD pheno and genotypes in their twins' early development study, and a probability of $41 \%$ for co-occurrence ADHD in ASD patients. Nijmijer et al. [225] found genetic linkages between ASD and ADHD on chromosomes 7, 12, 15, 16, and 18. The "dual disorder" is characterized by increased psychopathology and psychosocial stress, more compromised cognitive and daily functions, including maladaptive behaviors, and poorer effects of therapy $[48,125,147,160,246,251]$. ASD and ADHD share multiple comorbidities, such as dysexecutive problems, increased anxiety, sensory integration, sleep, affective and central hearing processing disorders, developmental delay, OCD, and epilepsy [187, 223, 281]. These comorbid conditions will largely determine the clinical picture. Unfortunately, ADHD in autistic patients is generally not appropriately treated [160]. This could be due to the fact that ADHD was excluded in autism diagnosis in ICD-10, a path that has now been changed in DSM-5 and ICD-11.

Treatment of ADHD in patients with ASD should follow the same multimodal algorithms as for ADHD alone and should include psychoeducation [87, 219, 238], parental training [41, 85, 87], school-based measures (such as daily record cards [70, 80, 97], structured task organization, physical activity [39, 158, 302]), and medication [31, 285, 296]. ADHD medication is usually less effective, and SE are more pronounced in ASD patients, especially in those with ID [48, 85, 241, 255]. Cognitive training [56] and neurofeedback $[88,212,252]$ are less effective and more complex. Occupational therapy [49] is useful as an adjunct for improving comorbid sensory integration and dysexecutive problems.

Medication for ASD/ADHD targets modulating dopamine and epinephrinergic transmitter systems, thereby increasing dopamine availability in frontal areas and striatum, and downregulating dopamine moderators. Usually, two types of medication are distinguished: stimulants (methylphenidate, amphetamine, lis-dexamphetamine) and nonstimulants (atomoxetine and alpha-2 agonists).

Stimulants. Effectiveness and compatibility of methylphenidate, the most frequently used ADHD medication, have multiply been proven in patients with ASD and ADHD, with and without ID [11, 255, 
Table 4 Selected antipsychotics used in children and adolescents with ASD

\begin{tabular}{|c|c|c|c|c|}
\hline Drug & $t 1 / 2^{\mathrm{a}}$ & Recommended Dose (mg/kg/d) & Spec. remarks & References $^{b}$ \\
\hline Risperidone & $22 h^{c}$ & $0.005-0.02^{\mathrm{d}}$ also available as syrup & Standard therapy ${ }^{\mathrm{e}}$ & {$[42,64,153,207,278]$} \\
\hline Aripiprazole & $60-80 \mathrm{~h}$ & $0.05-0.1^{\dagger}$ & Standard therapy ${ }^{g}$ & {$[46,62,66,82,196,231]$} \\
\hline Olanzapine & $30-60 \mathrm{~h}$ & 0.1 & SE: sedation, metabolic & {$[93,136,291]$} \\
\hline Paliperidone & & $0.5-2$ & No advantage over risperidone & [98] \\
\hline Quetiapine & $7 \mathrm{~h}$ & $0.5-4$ & Also acts against $G A D^{h}$ & {$[109,122,200]$} \\
\hline Ziprasidone & $6 \mathrm{~h}$ & $0.02-0.4$ & Cardiac SE (QTC ^) & {$[69,195]$} \\
\hline Pimozide & $55 \mathrm{~h}$ & $0.02-0.08$ & FGA, therapy resistant tics & [79] \\
\hline
\end{tabular}

Table 5 Selected antidepressants used in children and adolescents with ASD to treat depression, anxiety, and OCD

\begin{tabular}{|l|l|l|l|l|}
\hline Drug & $t 1 / 2^{\mathrm{a}}$ & Recommended Dose $(\mathrm{mg} / \mathrm{kg} / \mathrm{d})$ & Specific remarks & \\
\hline Fluoxetine & $1-6 \mathrm{~d}$ & $0.4-0.8$ & SE: sleep \& eating problems & {$[135,169,253]$} \\
\hline Paroxetine & $12-22 \mathrm{~h}$ & 0.4 & Also effective against anxiety disord. and drug treatment & {$[242]$} \\
\hline Sertraline & $23-26 \mathrm{~h}$ & 1 & Well tolerated & {$[292]$} \\
\hline Agomelatin & $2.3 \mathrm{~h}$ & $0.5-1$ & MT1 \& $\beta 2$ agonist, no systematic studies in adolescents & {$[224]$} \\
\hline Duloxetin & $8-17 \mathrm{~h}$ & $0.4-1.2$ & SNRI & {$[224]$} \\
\hline Pregabalin & $6 \mathrm{~h}$ & $3-6-10$ & GABA analogon, pain killer, anticonvulsant, anxiolytic & No studies in ASD patients \\
\hline${ }^{\text {a }}[110],{ }^{\mathrm{b}}$ as related to ASD & & &
\end{tabular}

282, 298]. In addition to the main ADHD symptoms, executive and nonexecutive memory, reaction time, reaction time variability, response inhibition, social communication, and self-regulation are significantly improved with methylphenidate [51, 149, 298] with somewhat lower effect sizes (around 0.5) in children with ASD and ADHD, compared to normally developing children with ADHD. Because of the short $t 1 / 2$ of about 2 hours, stimulants are usually administered in a slow-release formulation, acting for 10-14 hours, depending on the preparation. About $70 \%$ of the normally developing children and half of the children with ASD and ID respond by improved behavior, especially with decreased impulsivity, improved cooperation and attention, and less hyperactivity. Behavioral improvement is more pronounced in children presenting with hyperactivity and normal IQ [4]. Careful dosage titration is recommended because of the large variability of efficacy that may be explained genetically [206]. The effect of methylphenidate on growth has been divergently debated with height deficits ranging from 0 to $4.7 \mathrm{~cm}$ with consistent use [258]. In children with severe side effects or decreased responsiveness to methylphenidate, amphetamine [284], or lisdexamphetamine $[52,54,127,145]$, an inactive amphetamine precursor that is activated in the erythrocytes may be recommended because of their larger effect sizes. Amphetamines, and especially lisdexamphetamine, also improve mood while acting.

Emotional dysregulation (irritability) is a common problem in children with ADHD and with ASD, with rates around $78 \%$ for both disorders [179]. Stimulants and atomoxetine act effectively but may also increase emotional dysregulation, although at a much lower prevalence of about $17 \%$ [104]. In addition, effects on sleep (longer sleep latency, decreased sleep efficiency, and shorter sleep duration) were observed with stimulant medication [167].

Atomoxetine. The norepinephrine reuptake inhibitor and NMDA receptor antagonist possesses good effectiveness $[123,124]$ and (compared to methylphenidate) a considerably longer $t 1 / 2$ of 35 hours and $99 \%$ plasma albumin binding. Because of its nearly continuous action, atomoxetine is a recommendable alternative to methylphenidate, although with a smaller effect size [5, 236, 244], especially in children who respond with pronounced SE to stimulants or are very difficult to handle in the morning and evening hours, when methylphenidate does not act. It may also be recommended in children with comorbid depression, tics, or anxiety disorders $[3,5]$. Atomoxetine needs a longer dosing period (up to 12 weeks) and may cause initial fatigue, headache, and gastrointestinal SE, wherefore the medication should initially be started in the evening hours. About $15 \%$ of the patients may react with increased aggression, requiring discontinuation of atomoxetine and either addition of risperidone [207] or aripiprazole [231] or switching to extended-release guanfacine [269, 270] or lisdexamphetamine [52].

Comparing atomoxetine and amphetamine derivates, higher effect sizes of methyplhenidate slow release preparations have been reported [121]. Small but significant cardiovascular effects have been reported for stimulant and atomoxetine medication [132], mainly small increases of the heart rate and of systolic or diastolic blood pressure [132]. Because significant cardiovascular effects may not be excluded 
Table 6 Anticonvulsants selected

\begin{tabular}{|c|c|c|c|c|}
\hline Drug & $t 1 / 2(\mathrm{~h})^{\mathrm{a}}$ & Recommended Dose $(\mathrm{mg} / \mathrm{kg} / \mathrm{d})$ & Comments & References $^{b}$ \\
\hline \multirow[t]{2}{*}{ Ethosuximide } & 53 & $10-20-40$ & Absences, well tolerated & [95]e \\
\hline & & & No effect on behavior, additive to VPS & \\
\hline \multirow[t]{4}{*}{ Valproic acid } & $12-16$ & $10-15-30$ & Enhances GABA-ergic inhibition & {$[96,136]$} \\
\hline & & & Cortical hyperconnectivity, increases risk & \\
\hline & & & Of ASD and malformation when & \\
\hline & & & Administered during pregnancy & \\
\hline \multirow[t]{2}{*}{ Lamotrigine } & $25-50$ & $0.5-4$ & Against gen. and PE, well tolerated & [23] \\
\hline & & & Against BSD, no effect on behavior & \\
\hline \multirow[t]{2}{*}{ Levetiracetam } & 7 & $20-40-60$ & Against generalized and PE, SE tiredness & [96] \\
\hline & & & No effect on behavior & \\
\hline Clobazam & 18 & $0.2-0.8$ & Add-on against prim. generalized and PE & [83] \\
\hline Clonazepam & $18-50$ & $0.01-0.4$ & Against myoclonus epilepsy, SE: dizziness, ataxia & [83] \\
\hline \multirow[t]{2}{*}{ Gabapentin } & & $10-40$ & Add-on against PE and sec. generalized & \\
\hline & & & Epilepsy, SE tiredness, DRESSC & [115] \\
\hline Sultiame & 24 & $5-6$ & SE: ataxia, paresthesia, anorexia & \\
\hline \multirow[t]{4}{*}{ Topiramate } & $19-25$ & $1-4 / 2$ & Against PE and generalized epilepsy, & \\
\hline & & & LGS $^{d}$, SE tiredness & \\
\hline & & & Weight loss, cognitive & {$[68,133]$} \\
\hline & & & impairment & \\
\hline Vigabatrin & $5-8$ & $20-60 / 2$ & & \\
\hline
\end{tabular}

in a small subgroup of patients (e.g., with slow drug metabolism), occasional blood pressure checks are recommended.

Alpha-2-agonists. Clonidine and extended-release guanfacine are less effective medications against ADHD core symptoms with some antitic potential, pronounced tiredness, and gastrointestinal SE, which may lead to discontinuing the medication. Hyperactivity and impulsivity are improved in about $45 \%$ of cases [144, 199, 241, 270, 294].

Other treatments for $A D H D$. Mindfulness-based [1, 259, 268] and neurofeedback therapies [138] have been tried with some success in children with ASD and ADHD.

\section{Affective Disorders}

Due to the fact that antidepressant medication is of questionable effect in children and adolescents with ASD, their use may generally not be recommended. There is no clear-cut evidence that this recommendation is also valid for patients with severe depression, and the widespread use of antidepressant medication reflects this challenge, especially in the light that the prevalence of comorbid depression in autistic patients is fourfold compared to the nonautistic population [318]. Combining antidepressants with (low-dose) antipsychotic medication may generally be recommended for augmenting antidepressant effects in therapy resistant depressive patients and-although with low evidence [78]-in suicidal patients. This relates to the long period needed for antidepressant drug effects to become evident and to the effect of an- tipsychotics to reduce initially present internal drive and suicidality. Psychotherapy adds to antidepressant therapy for light to medium severe depression in the short term but better in the long term. For severe depression, combining psycho and pharmacotherapy is recommended in normotypic children $[40,65]$.

Suicidality has been reported in $21.3 \%(7-47 \%)$ of patients with ASD [142, 324]. Suicidal ideation is very common in adolescents with ASD, especially in Asperger's autists, and is largely related to their increased vulnerability to stress, anxiety, and depression, their inflexibility, and their proneness to become bullied or sexually abused [142].

Bipolar disorders are detected in $6-21 \%$ of adult ASD patients [307], and 30\% of bipolar I patients meet the criteria for ASD [161]. Data for children and adolescents are still lacking. Therapeutic options include SGA, valproic acid, AD medication if severe depressive symptoms are present, and lithium. Lithium medication also improves social functioning in animals and adults [190]. Its use may be especially limited in children because of the narrow therapeutic range, its effect on thyroid function, the resulting need of a highly compliant and supportive environment, and the considerable and poorly tolerated emotional indifference created by the drug $[208,277]$.

\section{Anxiety Disorders}

About $40 \%$ of children with ASD present with various anxiety disorders, phobias including social phobia, general, and separation anxiety disorder, and OCD [323]. They also often react with symptoms of anxiety 
or even panic in reaction to changes in their environment. An early study [292] reported beneficial effects with low-dose AD medication against anxieties. Stachnik et al [290] reviewed the beneficial effect of neuroleptics for anxiety disorders in children with ASD. High doses of antidepressants may reduce OCD symptoms in normotypic children. Unfortunately, their effectiveness is not confirmed in children with ASD [169, $222,253]$, possibly because of the background similarities of ASD and OCD [271].

In general, the treatment methods of choice for fears and OCD are parent training, play therapy, and cognitive behavioral therapy (CBT) [6, 60]. Antidepressants in higher dosages may be tried in individual patients as an adjunct to cognitive therapies. Because of the poor flexibility of patients with ASD, CBT may be very laborious in autistic children and adolescents.

\section{Medication Against Sleep Disorders}

Medication may be helpful in inducing and improving disturbed sleep but should be provided with caution: melatonin will improve sleep rhythm in $85 \%$ of the children with ASD even in those without disturbed melatonin circadian rhythm at a daily dosage of 1-6 mg given 30 minutes before bedtime [108, 267]. Advancing sleep onset will require a smaller dose of $0.2-0.5 \mathrm{mg}$ given $3-5 \mathrm{~h}$ prior to the desired sleep time $[32,175]^{9}$.

Other sleep stimulating agents, like valerian, passion flower, and hops provide placebo support; benzodiazepines, zolpidem, and zaleplon act on GABA receptors, helping in inducing sleep but usually have a long $t 1 / 2$, decrease REM sleep phases, but lead to habituation, to losing sleep induction effects during prolonged use, and to promoting anxiety [234]. Sleep-inducing antidepressants like trazodone are commonly used. For contraindications (tricyclics, mirtazapine), see Sect. 3.2.

Restless legs syndrome $[59,280]^{10}$, another syndrome disturbing sleep and quality of life based on a genetic predisposition, dysregulation of iron metabolism, and the dopaminergic system, suggest considering iron deficiency as a cause of sleep disturbance [308].

Other sleep-stimulating agents, like valerian, passion flower, and hops, provide placebo support; benzodiazepines, zolpidem, and zaleplon act on GABA receptors, helping in inducing sleep but usually have a long $t 1 / 2$, decrease REM sleep phases, lead to habituation, may lose sleep induction effects and promote anxiety during prolonged use [234]. Sleep-inducing antidepressants like trazodone ${ }^{11}$ are commonly used.

\footnotetext{
9 These two references do not primarily refer to children with ASD.

${ }^{10}$ General description.

11 Trittico $^{\circledR}$
}

For contraindications (tricyclics, mirtazapine), see Sect. 3.2.

Benzodiazepines, especially those targeting $\mathrm{GABA}_{\mathrm{A}}$ receptor subtypes, may attenuate ASD symptoms [216]. The clinical significance of this effect is not known at present ${ }^{12}$.

\section{Convulsions and Epilepsy}

Epilepsy (more than one convulsion) occurs in about $5-46 \%$ of children with ASD, (compared to $1-2 \%$ in children not on the spectrum), depending on the clinical sample and the severity of ID [287]. Comorbid epilepsy adds to the impact of ASD on quality of life [303] because of a number of additional problems, such as cognitive, speech developmental, sleep, affective, medical, social, and behavioral issues [90, 118]. Phenotypes and causes are still insufficiently researched.

Mitochondrial respiratory chain defects have been detected as an important link between epilepsy and ASD [315]. In addition, three ASD associated syndromes with known genetic cause, tuberous sclerosis, Rett's syndrome, and fragile $\mathrm{X}$ syndrome, are associated with epilepsy. Another group of disorders, epileptic encephalopathies, have been described in the context of brain dysfunction and increasing autistic symptomatology [74], affecting about $40 \%$ of children with convulsions in early childhood. These include early myoclonic encephalopathies, West, Dravet, Lennox Gastaud, and Landau-Kleffner syndromes, myoclonus epilepsy in nonprogressive encephalopathies, and continuous spike waves in slow-wave sleep (CSWS) [303]. Risk factors include epilepsies with known structural defects, bilateral frontal EEG changes, and persistent hypsarrhythmia [303].

\section{Gastrointestinal Issues}

Gastrointestinal distress related to constitutional, behavioral, and inflammatory causes is frequently observed in children with ASD and may be related to altered ASD severity [140]. Alterations of the intestinal microbiota, permeability, and functioning may, for example, alter intestinal serotonin metabolism and cause hyperserotoninemia, alter immune responses, and even brain functioning and behavior via the gut-brain axis $[12,193]$. Attempts to influence these disturbances by diets (such as a glutenfree diet), probiotics, antibiotic or other "treatments" such as detoxification, would need careful prospective randomized clinical trials, precise diagnostics, and well-established clinical algorithms. At present, this clinical evidence is not available [240]

\footnotetext{
12 Alterations of the excitatory/inhibitory CNS imbalance in children with ASD? [99].
} 
Irritability, Aggression, Disruptive, and Self-Injuring Behavior

Impulsive aggression and related disruptive behavior, as well as self-injuring behavior are frequently observed in ASD/ADHD and are the leading cause for school suspension, clinical referrals, and ward admissions [182]. Positive parenting [71], early intensive psychosocial and behavioral interventions [60, 76], specific multisystemic programs, such as multisystemic therapy [131] or the Fast Track program [25, 55], and psychosocial interventions such as T-MAY [279] or TRAAY [276], and group sessions for social competence [101] lead to significant improvements of adaptive behavior. Recommendations for medical treatment include stimulants (in the case of comorbid ADHD) and nonstimulant medication, SGAs (cf. Sect. 3.1), antidepressant and mood stabilizing agents $[48,68,75,91,116,159]$. In addition to pharmacotherapy, behavioral and social competence training, and parental counselling are strongly recommended.

\section{Sleep Disorders}

Independently of their intellectual capacity, up to 2/3 of children with ASD suffer from sleep problems: delayed sleep onset, frequent night awakenings, reduced total sleep time, dys and parasomnias [26, 57, $63,157,175,189,197,205,256,308,317]$. These problems often persist into adulthood. The causes range from poor sleep hygiene and inconsistent parental behavior [317], (self) regulatory problems and central excitatory/inhibitory imbalance, delayed sleep pattern maturation, a disturbed hypothalamic-pituitary-adrenal axis, and decreased and dysrhythmic melatonin secretion to decreased binding of melatonin to its transporter protein and melatonin receptor dysfunction [57, 141, 202]. Recently, slow-release melatonin ${ }^{13}$ was approved by the European Medicines Agency for the treatment of sleep disorders in children with ASD from the age of 2. In addition, anxiety [305], ADHD/ASD associated sleep and sensory integration problems [126] leading to increased external stimulation (or decreased stimulus filtering), and cerebral convulsions may disturb sleep and quality of life of affected children and, consequently, of the whole family. Therefore, sleep diagnostics and treatment are important for both children with ASD and their families [174, 308].

Restless legs syndrome [59, 280], another syndrome disturbing sleep and quality of life based on a genetic predisposition, dysregulation of iron metabolism, and the dopaminergic system, suggest considering iron deficiency as a cause of sleep disturbance [308].

Behavioral measures [30, 283, 314] like fixed bedtime routine, providing sleeping cues and a low stimulation evening routine, supporting self-soothing be-

13 Slenyto $^{\circledR}$. havior, light therapy ${ }^{14}$ [84], avoiding daytime sleeping, etc., and sensory integration therapy [325] have proven to be helpful, although with little evidence [30].

\section{Chronic Tic Disorders, Tourette Syndrome, and Stereotypies}

Chronic tic disorders and motor stereotypies are common comorbid movement disorders in children and adolescents with ASD [249]. The prevalence of chronic tic disorder is about $6.5 \%$ [281], about 10 times higher than in normally developing children. It is characterized by involuntary movements or utterings that vary in onset and frequency, depending on daytime and seasonal variations and stress exposure. Treatment is necessary if severity and frequency exceed subjective or environmental tolerance. Effective treatment options [249] (besides relaxation, stress reduction, and bio or neurofeedback) include antipsychotics such as risperidone, aripiprazole, or pimozide, eventually with added pentoxyfylline, and the anticonvulsant topiramate are effective, whereas haloperidole, levetiracetam, guanfacine, and atomoxetine, as well as metoclopramide and odansetron, have not proven effective [249, 262].

\section{Other Substances, Supplementary and Alternative Therapies}

Among the "newer" pharmacologic concepts (such as IGF-1, memantine, D-cycloserine, arbaclofen, and oxytocin [240, 300]), only three show promise for the future: oxytocin with the objective to improve sociogenic behavior, beta blockers to reduce stress, and the glutamate antagonist, 2-methyl-6(phenylethynyl)pyridine (MPEP), to reduce stereotypic behavior [94]. For the latter substance, it is feared that sociogenic behavior may deteriorate during treatment [297].

In the short term, intranasal oxytocin enhances motivation and attention to social stimuli, improves social initiative, understanding, learning [8, 22, 176], and better recognition of emotions [111]. Unfortunately, these improvements were not substantiated in long-term trials [7, 112, 313, 321, 322]. A metaanalysis [248] reported medium-effect sizes for prolonged oxytocin therapy in small samples. Reasons for the variation in oxytocin response include time dependency of the oxytocin response [230], single nucleotide polymorphisms of the oxytocin receptor [148], and lasting effects of postnatal stimulation of the oxytocin system [300]. When studying oxytocin effects patients and targets must be carefully selected. Therefore, the clinical usefulness of oxytocin is still a matter of debate [228, 306]. Melanocortin, stimulating oxytocin release, could be a useful alternative

1410.000 lux for $1 / 2 \mathrm{~h}$ in the early evening and/or morning in order to synchronize the circadian rhythm better. 
[215], but large clinical trials are lacking. Still, a special edition of "Brain Research" 15 provides a comprehensive overview about the state of research.

There is only limited evidence for using beta blockers for reducing stress-related autoaggressive behavior [312] or memantine for improving language and memory functions [233]. Defects of GABA-A receptors, leading to deficient synaptogenesis, have been demonstrated in fragile $\mathrm{X}$ syndrome, a pervasive developmental disorder with known genetic defect ${ }^{16}$. Ganaxolone, a strong GABA-A agonist, was used in a controlled clinical study $[29,188]$ and was found to be safe but only effective in a subgroup of patients with fragile $\mathrm{X}$ syndrome, high levels of anxiety, and low intellectual capacity.

Medical cannabis, especially for ADHD, tics, sleep problems, behavioral problems, and anxiety [2, 134, 247], may improve symptoms but does not lead to remission. Treatment evidence at present is limited to anecdotical reports and a few small studies; three further studies are to be expected. Treatment options should, therefore, be restricted to single patients in whom standard treatment did not improve severe symptoms.

Various behavioral and functional therapies, such as structured behavioral therapies [178, 254, 299], communication and social skills training [177, 213], occupational therapy [49, 194], mindfulness [259], play teaching [162], music [217, 289], and speech therapy, have been shown to have beneficial effects in improving development, behavior, speech, social functioning, and quality of life [146, 191, 192, 220, $221,275]$. Physical exercise is an effective treatment option, especially in children with dual disorder, ASD and ADHD [128, 286, 302].

Alternative, "natural" treatments seem less invasive, safer (there are no reports on dangerous action), more intuitive to understand, and easier to procure. Parents are concerned with the safety or side effects (listed in the package leaflet) of medication or are disappointed because conventional medication did not change the core symptoms of ASD [120]. Therefore, alternative therapies are very popular [186, 191, 316]; a third of the parents of children with ASD have tried "alternative", "integrative", or "complementary"17 therapies [185, 186, 191]. A higher educational level of the mothers predicted the use of alternative therapies [120]. Half of the families use alternative therapies, although they do not rate them as useful.

Most of these therapies are used as an adjunct to conventional therapy. Biologically based therapies (such as diet[239, 293], vitamins and minerals, food supplements such as omega-3 fatty acids [150],

\footnotetext{
15 Vol. 1580:1-232(2015).

16 Fragile X mental retardation 1 (FMR1) gene on chromosome X (Xa27.3).

17 Alternative and conventional medication.
}

herbal remedies, secretin), and mind-body interventions (such as prayer, shamanism, biofeedback, meditation, and relaxation) are more often perceived efficacious than body-based methods (such as sensory integration therapy [325], massage, craniosacral therapy, neurofeedback, and special exercises) or energy therapies (healing touch, energy transfer) [120]. Technology based interventions seem promising because of the attention sustaining potential, but, at present, evidence of the success of such approaches is poor [172, 250]. Examples are interventions for acquiring language skills [226], for differentiating facial expressions [19], treating food selectivity [20], or anxiety or stress management [37].

A number of physicians encourage multivitamins (49\%), essential fatty acids (25\%), melatonin (25\%), and probiotics (19\%), and discourage withholding $(76 \%)$ or delaying immunizations $(55 \%)$, chelation (61\%), anti-infectives (57\%), or secretin (43\%) [120]. It has to be stated that there is no clinical evidence for applying specific (e.g., gluten-free or pro-biotic) diets [203], vitamins ${ }^{18}[155,237]$, oligominerals, herbal medicine [311], transfer of energy, chelates ${ }^{19}$ [151], or biologicals such as secretin [180, 186]. It has been found that $10 \%$ of parents even use potentially dangerous "medication" such as "whole-brain extracts" [185]. Medication from the Far East, such as traditional Chinese medicine or acupuncture, or osteopathy may be useful in the short-term run in improving single symptoms (restlessness, sleep disturbance); the long-term outcome is rather dubious [45].

\section{Discussion}

Pharmacotherapy in children and adolescents with ASD may be helpful in overcoming otherwise not resolvable behavioral and attentional problems (see Table 2 for an overview of indications and classes of useful substances). Individualized treatment is always mandatory, Reviewing the extensive literature on pharmacotherapy of ASD, a few trends may be recognized:

1. Conventional therapy, although mostly funded on extensive controlled studies, has its limits, especially when treating irritability and temper tantrums. These problems should be restricted by early behavioral treatment. Unfortunately, these treatments are tedious and not available everywhere. In addition, the question of the impact of comorbid conditions has not been solved as yet.

2. Pharmacologic treatments are not sufficient; the primary ASD treatment, especially for children with intellectual disabilities, will remain structured and

\footnotetext{
18 This is disputed for vitamin D: evidence [155] vs. no evidence [204].

19 For heavy metal detoxication.
} 
functional therapy, as well as parental empowerment and support.

3. Therapies aiming at improving the core symptoms of ASD, such as social communication: novel therapies, e.g., oxytocin, are encumbered with the complex functioning of our social brain, which is outlined in the first days of life or even before.

4. At present, genetically based therapies are not visible on the horizon, mostly because the genetic background of ASD is so complex that it will probably need further years of intensive research to link clinical pictures to genetic variants and establish repair options.

Behavioral problems, including irritability, reactive and proactive aggression, disruptive and self-stimulating behavior, restlessness, and temper tantrums, are among the most important therapeutic targets in children with ASD. Because of their very limited flexibility [102] and working memory problems [117], children with ASD easily become despaired and helpless and express this in externalizing behavior that can become difficult to control. Pharmacologic treatment, mostly using antipsychotics, must find a compromise between behavioral control, oversedation, and (mostly metabolic) side effects.

Depressed mood and anxiety disorders call for psychotherapy and, in selected patients, for treatment with antidepressants. The problems with antidepressant medication are its reduced efficacy in autistic vs. normally developing children (see Sect. 3.2), and, again, walking the tightrope between brightening mood or reducing anxiety or obsessions and compulsions and an increased behavioral activation.

Sleep problems are observed in a majority of patients with ASD. Sleep hygiene and bedtime routines should be tried before trying medication, and sleeprelated side effects of stimulant therapy should also be considered as a promoting factor of sleep dysfunction. Melatonin is the first-line drug, especially for difficulties in falling asleep. It is effective in about twothirds and counterbalances inherited melatonin dysfunction. It should be noted that falling asleep with lights on (especially from computer or mobile phone screens) counteracts the action of melatonin medication.

Treatment of ADHD, one of the most prominent comorbid conditions of ASD with overlapping symptoms, is often a key factor in enabling social and intellectual learning, school attendance, and fighting restlessness and impulsivity. Problems are related to the reduced efficacy of pharmacotherapy compared to normotypic patients and a multitude of interacting problems, e.g., bipolar disorder and ADHD.

Convulsions, most frequently observed in children with ASD and ID, should be treated like in normally developing children (see Sect. 3.2.1). Attention should be paid to sedation, metabolic, learning inhibition side effects, and, and in adolescents, to teratogenic side effects for the offspring.

The rediscovery of the gut-brain axis is a relatively new field of research and might, therefore, be overestimated by parents. More prospective studies will shed light on the effects of dietary and probiotic measures. Alternative treatments are comprehensively largely overestimated for their effects, ranging from dietary to physical and possibly endangering measures. Because alternative "medications" are not controlled for their action in prospective randomized trials, it is difficult to argue against the use of such substances in the general public, mostly because "natural" substances are considered harmless and innocuous (see Sect. 3.4).

In summary, we compiled an overview on substances that may be advantageously used in children with ASD with the aim of improving social behavior, learning ability, and quality of life of the children and their environment. The approach is rather defensive, mostly targeting undesired symptoms. Future work and experience should focus on desired changes of core symptoms, on long-term efficacy, on reducing polypragmasia and undesired drug effects, and on avoiding overtreatment, especially if behavioral therapies are available as an alternative. On the other hand, the benefits of carefully prescribed medication should always be recognized.

Funding Open access funding provided by Medical University of Vienna.

Conflict of Interest The authors state that no author has a conflict of interest to declare.

Open Access This article is licensed under a Creative Commons Attribution 4.0 International License, which permits use, sharing, adaptation, distribution and reproduction in any medium or format, as long as you give appropriate credit to the original author(s) and the source, provide a link to the Creative Commons licence, and indicate if changes were made. The images or other third party material in this article are included in the article's Creative Commons licence, unless indicated otherwise in a credit line to the material. If material is not included in the article's Creative Commons licence and your intended use is not permitted by statutory regulation or exceeds the permitted use, you will need to obtain permission directly from the copyright holder. To view a copy of this licence, visit http://creativecommons.org/licenses/by/4.0/.

\section{References}

1. Aadil M, Cosme RM, Chernaik J. Mindfulness-based cognitive behavioral therapy as an adjunct treatment of Attention Deficit Hyperactivity disorder in young adults: A literature review. Cureus. 2017;9(5):e1269. https://doi.org/10.7759/ cureus.1269.

2. Agarwal R, Burke SL, Maddux M. Current state of evidence of cannabis utilization for treatment of autism spectrum disorders. BMC Psychiatry. 2019;19(328):1-10. https://doi. org/10.1186/s12888-019-2259-4.

3. Allen A, Kurlan R, Gilbert D, Dunn D, Dallee FR, Spencer T. Atomoxetine treatment in children with ADHD and comor- 
bid tic disorders. In: 16th World Congress of IACAPAP. Darmstadt: Steinkopff; 2004.pp.311-31.

4. Aman MG, Buican B, Arnold LE. Methylphenidate treatmentin children with borderline IQ and mental retardation: analysis of three aggregated studies. J Child Adolesc Psychopharmacol. 2003;13(1):29-40.

5. Aman MG, Smith T, Arnold LE, Corbett-Dick P, Tumuluru R, Hollway JA, et al. A review of atomoxetine effects in young people with developmental disabilities. Res Dev Disabil. 2014;35(6):1412-24. https://doi.org/10.1016/j.ridd.2014. 03.006 .

6. American Academy of Child and Adolescent Psychiatry Committee on Quality Issues. Practice parameter for the assessment and treatment of children and adolescents with obsessive-compulsive disorder. J Am Acad Child Adoles Psych. 2012;51(1):98-113.

7. Anagnostou E, Soorya L, Brian J, Dupuis A, Mankad D, Smile S, et al. Intranasal oxytocin in the treatment of autism spectrum disorder: a review of literature and early safety and efficacy data in youth. Brain Res Brain Res Protoc. 1580;2014:188-98. https://doi.org/10.1016/j.brainres. 2014.01.049.

8. Andari E, Duhamel JR, Zalla T, Herbrecht E, Leboyer M, Sirigu A. Promoting social behavior with oxytocin in highfunctioning autism spectrum disorders. Proc Natl Acad Sci Usa. 2010;107:4389-94.

9. Anderson LT, Campbell M, Grega DM, Perry R, Small AM, Green WH. Haloperidol in the treatment of infantile autism: effects on learning and behavioral symptoms. Am J Psychiatry. 1984;141:1195-202.

10. Antshel KM, Zhang-James Y, Faraone SV. The comorbidity of ADHD and autism spectrum disorder. Expert Rev Neurother. 2013;13(10):1117-28.

11. Arnold LE. Commentary: filling out the evidence base for treatment of attention-deficit hyperactivity disorder symptoms in children with intellectual and developmental disability: conclusions for clinicians - response to Simonoff et al. J Child Psychol Psychiatry Allied Discip. 2013;54(6):701-4.

12. Ashwood P, Krakowiak P, Hertz-Picciotto I, Hansen R, Pessah I, Van de Water J. Elevated plasma cytokines in autism spectrum disorders provide evidence of immune dysfunction and are associated with impaired behavioral outcome. Brain Behav Immun. 2011;25(1):40-5. https://doi.org/10. 1016/j.bbi.2010.08.003.

13. Asperger H. Die „Autistischen Psychopathen” im Kindesalter [The "Autistic Psychopaths" in Childhood]. Arch Psychiatr. 1944;117:76-136. https://doi.org/10.1007/ BF01837709.

14. Bachmann CJ, Manthey T, Kamp-Becker I, Glaeske G, Hoffmann F. Psychopharmacological treatment in children and adolescents with autism spectrum disorders in Germany. Res Dev Disabil. 2013;34(9):2551-63.

15. Bai D, Hon Kei Yip B, Windham GC, Sourander A, Francis $\mathrm{R}$, Yoffe $\mathrm{R}$, et al. Association of genetic and environmental factors with autism in a 5-country cohort. Jama Psychiatry. 2019;76(10):1035-43. https://doi.org/10.1001/ jamapsychiatry.2019.1411.

16. Bailey T. Beyond DSM: The role of auditory processing in attention and its disorders. Appl Neuropsychol Child. 2012;1(2):112-20.

17. Bakermans-Kranenburg MJ, van Ijzendoorn MH. Sniffing around oxytocin: review and meta-analyses of trials in healthy and clinical groups with implications for pharmacotherapy. Transl Psychiatry. 2013;3:e258. https://doi.org/ 10.1038/tp.2013.34.
18. Banaschewski T, Poustka L, Holtmann M. Autismus und ADHS über die Lebensspanne. Differenzialdiagnosen oder Komorbidität? [Autism and ADHD across the life span. Differential diagnoses or comorbidity?]. Nervenarzt. 2011;82(5):573-80. https://doi.org/10.1007/s00115-0103239-6.

19. Banire B, Al Thani D, Makki M, Qaraqe M, Anand K, Olcay C, Khowaja K, Mansoor B. Attention assessment: Evaluation of facial expressions of children with autism spectrum disorder. In. In: Universal access in human-computer interaction. Multimodality and assistive environments. Berlin Heidelberg: Springer; 2019. pp. 32-48. https://doi. org/10.1007/978-3-030-23563-5_4.

20. Banire B, Khowaja K, Mansoor B, Qaraqe M, Al Thani D. Reality-based technologies for children with autism spectrum disorder: a recommendation for food intake intervention. In: Advances in neurobiology. Berlin Heidelberg: Springer; 2020. pp. 679-93. https://doi.org/10. 1007/978-3-030-30402-7_26.

21. Baribeau DA, Anagnostou E. Social communication is an emerging target for pharmacotherapy in autism spectrum disorder-a review of theliterature on potential agents. JCan Acad Child Adolesc Psychiatry. 2014;23(1):20-30.

22. Bartz JA, Hollander E. Oxytocin and experimental therapeutics in autism spectrum disorders. Prog Brain Res. 2008;170:451-62.

23. Belsito KM, Law PA, Kirk KS, Landa RJ, Zimmerman AW. Lamotrigine therapy for autistic disorder: a randomized, double-blind, placebo-controled trial. JAutism DevDisord. 2001;31:175-81.

24. Besag FM. Epilepsy in patients with autism: links, risks and treatment challenges. NDT. 2017;14:1-10. https://doi.org/ 10.2147/NDT.S120509.

25. Bierman KL, Coie J, Dodge K, Greenberg M, Lochman J, McMohan R, et al. School outcomes of aggressivedisruptive children: prediction from kindergarten risk factors and impact of the fast track prevention program. Aggr Behav. 2013;39(2):114. https://doi.org/10.1002/ab. 21467.

26. Blackmer AB, Feinstein JA. Management of sleep disorders in children with neurodevelopmental disorders: A review. Pharmacotherapy. 2016;36(1):84-98. https://doi.org/10. 1002 /phar. 1686.

27. Bolognani F, Del Valle Rubido M, Squassante L, Wandel C, Derks M, Murtagh L, et al. A phase 2 clinical trial of a vasopressin Vla receptor antagonist shows improved adaptive behaviors in men with autism spectrum disorder. Sci Transl Med. 2019;11(491):eaat7838. https://doi.org/10. 1126/scitranslmed.aat7838.

28. Bowers K, Lin PI, Erickson C. Pharmacogenomic medicine in autism: challenges and opportunities. Paediatr Drugs. 2015;17(2):115-24.

29. Braat S, Kooy RF. Insights into GABA-A ergic system deficits in fragileX syndrome lead to clinical trials. Neuropharmacology. 2015;88:48-54.

30. Brown CA, Kuo M, Phillips L, Berry R, Tan M. Non-pharmacological sleep interventions for youth with chronic health conditions: A critical review of the methodological quality of the evidence. Disab Rehab. 2013;35(15):1221-55. https://doi.org/10.3109/09638288.2012.723788.

31. Brown KA, SamuelS, PatelDR. Pharmacologicmanagement of attention deficit hyperactivity disorder in children and adolescents: a review for practitioners. Translat Pediatr. 2018;7(1):36-47. https://doi.org/10.21037/tp.2017.08.02.

32. Bruni O, Alonso-Alconada D, Besag F, Biran V, Braam W, Cortese S, et al. Current role of melatonin in pediatric neurology: clinical recommendations. Eur J Paed Neurol. 
2015;19(2):122-33. https://doi.org/10.1016/j.ejpn.2014 12.007.

33. Burnashev N, Szepetowski P. NMDA receptor subunit mutations in neurodevelopmental disorders. Curr Opin Pharmacol. 2015;20:73-82.

34. Canitano R. New experimental treatments for core social domain in autism spectrum disorders. Front Pediatr. 2014;2(Article 61):1-6.

35. Canitano R, Scandurra V. Psychopharmacology in autism: an update. Prog Neuropsychopharmacol Biol Psychiatry. 2011;35(1):18-28.

36. CarbonePS. Movingfromresearch topracticein theprimary care of children with autism spectrum disorders. Acad Pediatr. 2013;13(5):390-9. https://doi.org/10.1016/j.acap. 2013.04.003.

37. Carlier S, Van der Paelt S, Ongenae F, De Backere F, De Turck. Empowering children with ASD and their parents: design of a serious game for anxiety and stress reduction. Sensors. 2020;20(4):966. https://doi.org/10.3390/s20040966.

38. Hoglund Carlsson L, Norrelgen F, Kjellmer L, Westerlund J, Gillberg C, Fernell E. Coexisting disorders and problems in preschool children with autism spectrum disorders. Sci World J. 2013;213979. https://doi.org/10.1155/2013/ 213979.

39. Cerrillo-Urbina AJ, García-Hermoso A, Sánchez-López M, Pardo-Guijarro MJ, Santos Gómez JL, Martínez-Vizcaíno V. The effects of physical exercise in children with attention deficit hyperactivity disorder: a systematic review and meta-analysis of randomized control trials. Child Care Health Dev. 2015;41(6):779-88. https://doi.org/10.1111/ cch. 12255.

40. Chambless DL, Ollendick TH. Empirically supported psychological interventions: controversies and evidence. Annu Rev Psychol. 2001;52:685-716.

41. Charach A, Carson P, Fox S, Ali MU, Beckett J, Lim CG. Interventions for preschool children at high risk for ADHD: a comparative effectiveness review. Pediatrics. 2013;131(5):e1584-e604.

42. Chavez B, Chavez-Brown M, Rey JA. Role of risperidone in children with autism spectrum disorder. Ann Pharmacother. 2006;40(5):909-16.

43. Chavez B, Chavez-Brown M, Sopko MA Jr., Rey JA. Atypical antipsychotics in children with pervasive developmental disorders. Paediatr Drugs. 2007;9(4):249-66.

44. Chen J, Alberts I, Li X. Dysregulation of the IGF-I/ PIeK/AKT/TOR signaling pathway in autism spectrum disorders. Int J Dev Neurosci. 2014;35:35-41. https://doi. org/10.1016/j.ijdevneu.2014.03.006.

45. Cheuk DK, Wong V, Chen WX. Acupuncture for autism spectrum disorders (ASD). Cochrane Database Syst Rev. 2011; https://doi.org/10.1002/14651858.CD007849.pub2.

46. Ching H, Pringsheim T. Aripiprazole for autism spectrum disorders (ASD). CochraneDatabaseSystRev. 2012; https:// doi.org/10.1002/14651858.CD009043.pub2.

47. Chini B, Leoncino M, Gigliucci V. Oxytocin in the developing brain: Relevance as disease-modifying treatment in autism spectrum disorders. In Carlo Sala and Chiara Verpelli, editors, Neu Syn Dysfunct Autism Spect Dis Intellect Disab. 2016;253-266. London, San Diego, Oxford: Academic Press.

48. Clark B, Bélanger SA. ADHD in children and youth: part 3 -assessment and treatment with comorbid ASD, ID, or prematurity. Paediatr Child Health. 2018;23(7):485-90. https://doi.org/10.1093/pch/pxy111.

49. Clark GF, Watling R, Parham LD, Schaaf R. Occupational therapy interventions for children and youth with challenges in sensory integration and sensory processing: A school-based practice case example. Am J Occupat
Ther. 2019;73(3):7303390010p1-7303390010p8. https:// doi.org/10.5014/ajot.2019.733001.

50. Clarke TK, Lupton MK, Fernandez-Pujals AM, Starr J, Davies $\mathrm{G}$, Cox S, et al. Common polygenic risk for autism spectrum disorder (ASD) is associated with cognitive ability in the general population. Mol Psychiatry. 2015;21(3):419-25. https://doi.org/10.1038/mp.2015.12.

51. Coghill DR, Seth S, Pedroso S, Usala T, Currie J, Gagliano A. Effects of methylphenidate on cognitive functions in children and adolescents with attention-deficit/hyperactivity disorder: evidence from a systematic review and a metaanalysis. Biol Psychiatry. 2014;76:603-15. https://doi.org/ 10.1016/j.biopsych.2013.10.005.

52. Coghill DR, Banaschewski T, Nagy P, Hernández Otero I, Soutullo C, Yan B, et al. Long-term safety and efficacy of lisdexamfetamine dimesylate in children and adolescents with ADHD: A phase IV, 2-year, open-label study in Europe. CNS Drugs. 2017;31(7):625-38. https://doi.org/10.1007/ s40263-017-0443-y.

53. Coleman DM, Adams JB, Anderson AL, Frye RE. Rating of the effectiveness of 26 psychiatric and seizure medications for autism spectrum disorder: results of a national survey. J Child Adolesc Psychopharmacol. 2019;29(2):107-23. https://doi.org/10.1089/cap.2018.0121.

54. Comiran E, Kessler FH, Froehlich PE, Limberger RP. Lisdexamfetamine: A pharmacokinetic review. Eur J Pharmaceut Sci. 2016;89:172-179. https://doi.org/10.1016/j.ejps.2016. 04.026.

55. Conduct Problems Prevention Research Group. The effects of the Fast Track preventive intervention on the development of conduct disorder across childhood. Child Dev. 2011;82(1):331-45. https://doi.org/10.1111/j.1467-8624. 2010.01558.x.

56. Cortese S, Ferrin M, Brandeis D, Buitelaar J, Daley D, Dittmann RW, etal. Cognitive training for attention-deficit/ hyperactivity disorder: Meta- analysis of clinical and neuropsychological outcomes from randomized controlled trials. J Am Acad Child Adoles Psych. 2015;54(3):164-174. https://doi.org/10.1016/j.jaac.2014.12.010.

57. Cortesi F, Giannotti F, Ivanenko A, Johnson K. Sleep in children with autistic spectrum disorder. Sleep M. 2011;11(7):659-64. https://doi.org/10.1016/j.sleep.2010. 01.010 .

58. Craig F, Savino R, Trabacca A. A systematic review of comorbidity between cerebral palsy, autism spectrum disorders and attention deficit hyperactivity disorder. Eur J Paediatr Neurol. 2019;23(1):31-42. https://doi.org/10.1016/j.ejpn. 2018.10.005.

59. Dauvilliers Y, Winkelmann J. Restless legs syndrome: update on pathogenesis. Curr Opinoion Pulm Med. 2013;19(6):594-600. https://doi.org/10.1097/MCP.0b013e $328365 \mathrm{ab} 07$.

60. Dawson G, Burner K. Behavioral interventions in children and adolescents with autism spectrum disorder: a review of recent findings. Curr Opin Pediatr. 2011;23(6):616-20.

61. De Hert M, Dobbelaere M, Sheridan EM, Cohen D, Correll CU. Metabolic and endocrine adverse effects of secondgeneration antipsychotics in children and adolescents: a systematic review of randomized, placebo controlled trials and guidelines for clinical practice. Eur psychiatr. 2011;26(3):144-58.

62. Deb S, Farmah BK, Arshad E, Deb T, Roy M, Unwin GL. The effectiveness of aripiprazolein themanagement of problem behaviour in people with intellectual disabilities, developmental disabilities and/or autistic spectrum disorder-a systematic review. Res Dev Disabil. 2014;35(3):711-25. 
63. Devnani PA, HegdeAU.Autismand sleep disorders. JPediatr Neurosci. 2015;10(4):304-7.

64. Dinissen M, Dietrich A, van den Hoofdakker BJ, Hoekstra. Clinical and pharmacokinetic evaluation of risperidone for the management of autism spectrum disorder. Expert Opin Drug Metab Toxicol. 2015;11(1):111-24.

65. Dolle K, Schulte-Körne G. Evidenztabelle Psycho- und Pharmakotherapie im Vergleich und in Kombination zur Leitlinie „Behandlung von depressiven Störungen bei Kindern und Jugendlichen" [Table of evidence Psychoand pharmacotherapy, comparing and combining the guideline Treatment of depressive disorders in children and adolescents. 2012. http://www.awmf.org/leitlinien/ aktuelle-leitlinien.html. Accessed: 17Jun 2021.

66. Douglas-Hall P, Curran S, Bird V, Taylor D. Aripiprazole: a review of its use in the treatment of irritability associated with autistic disorder patients aged 6-17. J Cent Nerv Syst Disord. 2011;12(3):143-53.

67. Dove D, Warren Z, McPheeters ML, Taylor JL, Sathe NA, Veenstra-VanderWeele J. Medications for adolescents and young adults with autism spectrum disorders: a systematic review. Pediatrics. 2012;130(4):717-26, 2012. https://doi. org/10.1542/peds.2012-0683.

68. Doyle CA, McDougle CJ. Pharmacologic treatments for the behavioral symptoms associated with autism spectrum disorders across the lifespan. Dia Clin Neurosci. 2012;14(3):263-79, 2012.

69. Duggal HS. Ziprasidone for maladaptive behavior and attention-deficit/hyperactivitydisordersymptomsinautistic disorder. J Child Adolesc Psychopharmacol. 2007;2:261-3.

70. DuPaul GJ, Gormley MJ, Laracy SD. School-based interventions for elementary school students with ADHD. Child Adolescent Psych Clin N Am. 2014;23(4):687-97. https:// doi.org/10.1016/j.chc.2014.05.003.

71. Dyches TT, Smith TB, Korth BB, Roper SO, Mandleco B. Positive parenting of children with developmental disabilities: a meta-analysis. Res Develop Disabil. 2012;33(6):2213-20. https://doi.org/10.1016/j.ridd.2012.06.015.

72. Earle JF. An introduction to the psychopharmacology of children and adolescents with autism spectrum disorder. J Child Adoles Psych Nurs. 2016;29(2):62-71. https://doi. org/10.1111/jcap.12144.

73. Elsabbagh M, Divan G, Koh YJ, Kim YS, Kauchali S, Marcin $\mathrm{C}$, et al. Global prevalence of autism and other pervasive developmental disorders. Autism Res. 2012;5(3):160-79. https://doi.org/10.1002/aur.239.

74. Engel J Jr. A proposed diagnostic scheme for people with epileptic seizures and with epilepsy: report of the ilae task force on classification and terminology. Epilepsia. 2001;42:796-803.

75. Epstein R, Fonnesbeck C, Williamson E, Kuhn T, Lindegren ML, Rizzone K, Krishnaswami S, Sathe N, Ficzere CH, Ness GL, Wright GW, Raj M, Potter S, McPheeters M. Psychosocial and pharmacologic interventions for disruptive behavior in children and adolescents. comparative effectiveness review number 154. 2015. https://effectivehealthcare. ahrq.gov/sites/default/files/pdf/disruptive-beha viordisorder_research.pdf. Accessed: 17 Jun 2021

76. Epstein RA, Fonnesbeck C, Potter S, Rizzone KH, McPheeters M. Psychosocial interventions for child disruptive behaviors: a meta-analysis. Pediatrics. 2015;136(5):947-60. https://doi.org/10.1542/peds.20152577.

77. Erickson CA, Veenstra-Vanderweele JM, Melmed RD, McCracken JT, Ginsberg LD, Sikich L, et al. Stx209 (Arbaclofen) for autism spectrum disorders: an 8-week open-label study.
J Autism Dev Disord. 2014;44(4):958-64. https://doi.org/ 10.1007/s10803-013-1963-z.

78. Ernst CL, Goldberg JF. Antisuicide properties of psychotropic drugs: a critical review. Harv Rev Psychiatry. 2004;12(1):14-41. https://doi.org/10.1080/ 10673220490425924.

79. Ernst M, Magee HJ, Gonzalez NM, Locascio JJ, Rosenberg CR, Campbell M. Pimozide in autistic children. PsychopharmacolBull. 1992;28(2):187-91.

80. Evans SW, Owens JS, Wymbs BT, Ray AR. Evidence-based psychosocial treatments for children and adolescents with attention deficit/hyperactivity disorder. J Clin Child Adolesc Psychol. 2018;47(2):157-98. https://doi.org/10.1080/ 15374416.2017.1390757.

81. Farmer C, Thurm A, Grant P. Pharmacotherapy for the core symptoms in autistic disorder: current status of the research. Drugs. 2013;73(4):303-14. https://doi.org/10. 1007/s40265-013-0021-7.

82. Farmer CA, Aman MG. Aripiprazole for the treatment of irritability associated with autism. Expert Opin Pharmacother. 2011;12(4):635-40.

83. Faulkner MA, Singh SP. Neurogenetic disorders and treatment of associated seizures. Pharmacotherapy. 2013;33(3):330-43. https://doi.org/10.1002/phar.1201.

84. Faulkner SM, Bee PE, Meyer N, Dijk DJ, Drake RJ. Light therapies to improve sleep in intrinsic circadian rhythm sleep disorders and neuro-psychiatric illness: a systematic review and meta-analysis. Sleep Med Rev. 2019;46:108-23. https://doi.org/10.1016/j.smrv.2019.04.012.

85. Feldman ME, Charach A, Bélanger SA. ADHD in children and youth: part 2-treatment. Paediatr Child Health. 2018;23:462-72. https://doi.org/10.1093/pch/pxy113.

86. Fernell E, Eriksson MA, Gillberg C. Early diagnosis of autism and impact on prognosis: a narrative review. Clin Epidemiol. 2013;5:33-43. https://doi.org/10.2147/clep. s41714.

87. Ferrin M, Moreno-Granados JM, Salcedo-Marin MD, RuizVeguilla M, Perez-Ayala V, Taylor E. Evaluation of a psychoeducation programme for parents of children and adolescents with ADHD: Immediate and long-term effects using a blind randomized controlled trial. Eur Child Adolesc Psychiatry. 2014;23(8):637-47.

88. Flatz T, Gleußner M. Neurofeedbacktherapiebei ADHS und Autismus [neurofeedback therapy for ADHD and Autism]. Paediatr Paedol. 2014;49:22-7.

89. Flippin M, Reszka S, Watson LR. Effectiveness of the picture exchange communication system (PECS) on communication and speech for children with autism spectrum disorders: a meta-analysis. Am J Speech Lang Pathol. 2010;19(2):178-95. https://doi.org/10.1044/10580360(2010/09-0022).

90. Francis A, Msall M, Obringer E, Kelley K. Children with autism spectrum disorder and epilepsy. Pediat Ann. 2013;42(12):255-60. https://doi.org/10.3928/0090448120131122-10.

91. FrazierTW, Youngstrom EA, HaycookT, SinoffA, Dimitrou F, Knapp J, et al. Effectiveness of medication combined with intensive behavioral intervention for reducing aggression in youth with autism spectrum disorder. J Child Adolesc Psychopharmacol. 2010;20(3):167-77.

92. Frazier TW, Shattuck PT, Narendorf SC, Cooper BP, Wagner $\mathrm{M}$, Spitznagel EL. Prevalence and correlates of psychotropic medication use in adolescents with an autism spectrum disorder with and without caregiver-reported attentiondeficit/hyperactivity disorder. J Child Adolesc Pharmacol. 2011;21(6):571-9. https://doi.org/10.1089/cap.2011.0057. 
93. FrémauxT, Reymann JM, ChevreuilC, Bentué-Ferrer D. Prescription del'olanzapine chez l'enfant et l'adolescent [Verschreibung von Olanzapin bei Kindern und Jugendlichen]. Encephale. 2007;33(2):188-96.

94. Frye RE. Social skills deficits in autism spectrum disorder: potential biological origins and progress in developing therapeutic agents. CNSDrugs. 2018;32(8):713-34. https:// doi.org/10.1007/s40263-018-0556-y.

95. Frye RE, Sreenivasula S, Adams JB. Traditional and nontraditional treatments for autism spectrum disorder with seizures: an on-line survey. BMCPediatr. 2011;11:37.

96. Frye RE, Rossignol D, Casanova MF, Brown GL, Martin V, Edelson S, et al. A review of traditional and novel treatments for seizures in autism spectrum disorder: findings from a systematic review and expert panel. Front Public Health. 2013;1(31):1-26. https://doi.org/10.3389/fpubh. 2013.00031.

97. Gaastra GF, Groen Y, Tucha L, Tucha O. The effects of classroom interventions on off-task and disruptive classroom behavior in children with symptoms of attention-deficit/ hyperactivity disorder: A meta-analytic review. PLOS ONE. 2016;11(2):e0148841:1-19. https://doi.org/10.1371/ journal.pone.0148841.

98. Gahr M, Kölle MA, Schönfeldt-Lecuona C, Lepping P, Freudenmann RW. Paliperidone extended-release: does it have a place in antipsychotic therapy? DDDT. 2011;11(5):125-46.

99. Gao R, Penzes P.Common mechanisms of excitatory and inhibitory imbalance in schizophrenia and autism spectrum disorders. Curr Molec Med. 2015;15(2):146-67.https:// doi. org/10.2174/1566524015666150303003028.

100. Garbarino VR, Lee Gilman T, Daws LC, Gould GG. Extreme enhancement or depletion of serotonin transporter function and serotonin availability in autism spectrum disorder. PharmacolRes. 2019;140:85-99. https://doi.org/10.1016/j. phrs.2018.07.010.

101. Gates JA, Kang E, Lerner MD. Efficacy of group social skills interventions for youth with autism spectrum disorder: a systematic review and meta-analysis. Clin Psychol Rev. 2017;52:164-81. https://doi.org/10.1016/j.cpr.2017. 01.006 .

102. Geurts HM, CorbettB, Solomon M. The paradox of cognitive flexibility in autism. Trends Cogn Sci. 2009;13(2):74-82. https://doi.org/10.1016/j.tics.2008.11.006.

103. Ghanizadeh A, Sahraeizadeh A, Berk M. A head-to-head comparison of Aripiprazole and Risperidone for safety and treating autistic disorders, a randomized double blind clinical trial. Child PsychiatryHum Dev. 2014;45(2):185-92.

104. Ghanizadeh A, Molla MAS, Olango GJ. The effect of stimulants on irritability in autism comorbid with ADHD: a systematic review. Neuropsych Dis Treat. 2019;15:1547-55 https://doi.org/10.2147/ndt.s194022.

105. Gilby KL, O’Brien TJ. Epilepsy, autism, and neurodevelopment: kindling a shared vulnerability? Epilepsy Behav. 2013;26(3):370-4. https://doi.org/10.1016/j.yebeh.2012. 11.002 .

106. Gjevik E, Sandstad B, Andreassen OA, Myhre AM, Sponheim E. Exploring the agreement between questionnaire information and DSM-IV diagnoses of comorbid psychopathology in children with autism spectrum disorders. Autism. 2014;19(4):433-42. https://doi.org/10.1177/ 1362361314526003.

107. Goel R, Hong JS, Findling RL, Ji NY. An update on pharmacotherapy of autism spectrum disorder in children and adolescents. Int Rev Psych. 2018;30(1):78-95. https:// doi. org/10.1080/09540261.2018.1458706.
108. Goldman SE, Adkins KW, Calcutt MW, Carter MD, Goodpaster RL, Wang L, et al. Melatonin in children with autism spectrum disorders: endogenous and pharmacokinetic profiles in relation to sleep. J Autism Dev Disord. 2014;44:2525-35.

109. Golubchik P, Sever J, Weizman A. Low-dose quetiapine for adolescents with autistic spectrum disorder and aggressive behavior: open-label trial. Clin Neuropharmacol. 2011;34(6):216-9.

110. Gründer G, Benkert O. Handbuch der Psychopharmakatherapie [Handbook of Psychopharmacotherapy]. Heidelberg: Springer; 2008.

111. Guastella AJ, Einfeld SL, Gray KM, Rinehart NJ, Tonge BJ, Lambert TJ, et al. Intranasal oxytocin improves emotion recognition for youth with autism spectrum disorders. Biol Psychiatry. 2010;67(7):692-4.

112. Guastella AJ, Hickie IB, McGuiness MM, Otis M, Woods EA, Disinger HM, et al. Recommendations for the standardisation of oxytocin nasal administration and guidelines for its reporting in human research. Psychoneuroendocrinology. 2013;38(5):612-25.

113. Guastella AJ, Hickie IB. Oxytocin treatment, circuitry and autism: a critical review of the literature placing oxytocin into the austism context. Biol Psychiatry. 2015;79(3):234-42. https://doi.org/10.1016/j.biopsych. 2015.06.028.

114. Guenot M. Indications et risques des techniques neurochirurgicales chez l'enfant présentant une épilepsie partielle pharmaco-résistante. [Surgical treatmentfor epilepsy in children wihth treatment resistant partial epilepsy: indications and complications]. Rev Neurol. 2004;160(Supplement 1):203-9.

115. Guglielmo R, Ioime L, Grandinetti P, Janiri L. Managing disruptive and compulsive behaviors in adult with autistic disorder with Gabapentin. J Clin Psychopharmacol. 2013;33(2):273-4.

116. Gurnani T, Ivanov I, Newcorn JH. Pharmacotherapy of aggression in child and adolescent psychiatric disorders. J Child Adol Psychopharmacol. 2016;26(1):65-73. https:// doi.org/10.1089/cap.2015.0167.

117. Habib A, Harris L, Pollick F, Melville C. A meta-analysis of working memory in individuals with autism spectrum disorders. PLoS ONE. 2019;14(4e0216198):1-25.

118. Hamiwka LD, Wirrell EC. Comorbidities in pediatric epilepsy: beyond "just" treating the seizures. JChild Neurol. 2009;24(6):734-42.

119. HandlemanJS, Harris SL. Preschool education programs for children with autism. Austin: ProEd; 2001.

120. Hanson E, Kalish LA, Bunce E, Curtis C, McDaniel S, Ware $\mathrm{J}$, et al. Use of complementary and alternative medicine among children diagnosed with autism spectrum disorder. J Autism Dev Disord. 2007;37(4):628-36. https://doi.org/ 10.1007/s10803-006-0192-0.

121. Hanwella R, Senanayake M, de Silva V.Comparative efficacy and acceptability of methylphenidate and atomoxetine in treatment of attention deficit hyperactivity disorder in children and adolescents: a meta-analysis. BMCPsychiatry. 2011;11(176):1-8. https://doi.org/10.1186/1471-244X-11176.

122. Hardan AY, Jou RJ, Handen BL. Retrospective study of quetiapine in children and adolescents with pervasive developmental disorders. JAutism Dev Disord. 2005;35(3):387-91.

123. Harfterkamp M, van de Loo-Neus G, Minderaa RB, van der Gaag RJ, Escobar R, Schacht A, et al. A randomized doubleblind study of atomoxetine versus placebo for attentiondeficit/hyperactivity disorder symptoms in children with autism spectrum disorder. J Am Acad Child Adol Psych. 
2012;51(7):733-41. https://doi.org/10.1016/j.jaac.2012.04. 011.

124. Harfterkamp M, Buitelaar JK, Minderaa RB, van de LooNeus G, van der Gaag RJ, Hoekstra PJ. Long-term treatment with atomoxetine for attention-deficit/ hyperactivity disorder symptoms in children and adolescents with autism spectrum disorder: An open-label extension study. J Child Adolesc Psychopharmacol. 2013;23(3):194-9. https://doi. org/10.1089/cap.2012.0012.

125. Hartley SL, Sikora DM. Which DSM-IV-TR criteria best differentiate high-functioning autism spectrum disorder from ADHD and anxiety disorders in older children? Autism. 2009;13(5):485-509. https://doi.org/10.1177/ 1362361309335717.

126. Hazen EP, Stornelli JL, O’Rourke JA, Koesterer K, McDougle CJ. Sensory symptoms in autism spectrum disorders. Harv Rev Psychiatry. 2014;22(2):112-24.

127. Heal DJ, Smith SL, Gosden J, Nutt DJ. Amphetamine, past and present-a pharmacological and clinical perspective. J Psychopharmacol. 2013;27(6):479-96. https://doi.org/ $10.1177 / 0269881113482532$.

128. Den Heijer AE, Groen Y, Tucha L, Fuermaier ABM, Janneke Koerts, Lange KW, et al. Sweat it out? The effects of physical exercise on cognition and behavior in children and adults with ADHD: a systematic literature review. J Neural Transm. 2017;124(Suppl 1):S3-S26. https://doi.org/10. 1007/s00702-016-1593-7.

129. Hellings JA, Weckbaugh M, Nickel EJ, Cain SE, Zarcone JR, Reese RM, et al. A double-blind, placebo-controlled study of valproate for aggression in youth with pervasive developmental disorders. J Child Adolesc Psychopharmacol. 2005;15(4):682-92. https://doi.org/10.1089/cap.2005.15. 682.

130. Henderson C, Wietjunge I, Kinoshita MN, Shumway M, Hammond RS, Postma FR, et al. Reversal of disease-related pathologies in the Fragile $\mathrm{X}$ mouse model by selective activation of GABA-B receptors with arbaclofen. Sci Transl Med. 2012;4(152):1-11.

131. Henggeler SW, Schaeffer CM. Multisystemic therapy: clinical overview, outcomes, and implementation research. Fam Proc. 2016;55(3):514-28. https://doi.org/10.1111/ famp./12232.

132. Hennissen L, Bakker MJ, Banaschewski T, CarucciS, Coghill D, Danckaerts M, et al. Cardiovascular effects of stimulant and non-stimulant medication for children and adolescents with ADHD: A systematic review and meta-analysis of trials of methylphenidate, amphetamines and atomoxetine. CNS Drugs. 2017;31(3):199-215. https://doi.org/10. 1007/s40263-017-0410-7.

133. Hirota T, Veenstra-Vanderweele J, Hollander E, Kishi T. Antiepileptic medications in autism spectrum disorder: a systematic review and meta-analysis. J Autism Dev Disord. 2014;44(4):948-57.

134. Hoch E, Niemann D, von Keller R, Schneider M, FriemelCM, Preuss UW, et al. How effective and safe is medical cannabis as a treatment of mental disorders? A systematic review. Eur Arch PsychiatryClin Neurosci. 2019;269(1):87-105. https:// doi.org/10.1007/s00406-019-00984-4.

135. Hollander E, Phillips A, Chaplin W, Zagursky K, Novotny S, Wasserman S, et al. A placebo controlled crossover trial of liquid fluoxetine on repetitive behaviors in childhood and adolescent autism. Neuropsychopharmacology. 2005;30(3):582-9.

136. Hollander E, Soorya L, Wasserman S, Esposito K, Chaplin W, Anagnostou E. Divalproex sodium vs. placebo in the treatment of repetitive behaviours in autism spectrum disorder. Int J Neuropsychopharmacol. 2006;9:209-13.
137. Hollander E, Wasserman S, Swanson EN, Chaplin W, Schapiro ML, Zagursky K, et al. A double-blind placebocontrolled pilot study of olanzapine in childhood/ adolescent pervasive developmental disorder. J Child Adolesc Psychopharmacol. 2006a;16(5):541-8.

138. Holtmann M, Steiner S, Hohmann S, Poustka L, Banaschewski T, BötelteS. Neurofeedbackin autism spectrum disorders. Dev Med Child Neurol. 2011;53:986-93. https:// doi.org/10.1111/j.1469-8749.2011.04043.x.

139. Hosenbocus S, Chahal R. Memantine: a review of possible uses in child and adolescent psychiatry. J Can Acad Child Adolesc Psychiatry. 2013;22(2):166-71.

140. Hsiao EY. Gastrointestinal issues in autism spectrum disorder. Harv Rev Psychiatry. 2014;22(2):104-11.

141. Hu VW, Sarachana T, Kim KS, Nguyen A, Kulkarni S, Steinberg ME, et al. Gene expression profiling differentiates autism case-controls and phenotypic variants of autism spectrum disorders: evidence for circadian rhythm dysfunction in severe autism. Autism Res. 2009;2(2):78-97. https://doi.org/10.1002/aur.73.

142. Huguet G, Contrejean Y, Doyen C. Troubles du spectre autistique et suicidalité. Encephale. 2014;41(4):362-9. https://doi.org/10.1016/j.encep.2014.08.010.

143. Hurwitz R, Blackmore R, Hazell P, Williams K, Woolfenden $\mathrm{S}$. Tricyclic antidepressants for autism spectrum disorders (ASD) in children and adolescents. Coch Data Syst Rev. 2012;;14(3):1-31,2012.

144. Huss M, ChenW, LudolphAG. Guanfacine extended release: A new pharmacological treatment option in Europe. Clin Drug Investigat. 2016;36(1):1-25. https://doi.org/10.1007/ s40261-015-0336-0.

145. Hutson PH, Pennick M, Secker R. Preclinical pharmacokinetics, pharmacology and toxicology of lisdexamfetamine: a novel d-amphetamine pro-drug. Neuropharmacology. 2014;87:41-50. https://doi.org/10.1016/j. neuropharm.2014.02.014.

146. Hyman SL, Levy SE, Myers SM, Councl on Children with Disabilities, Section on Developmental and Behavioral Pediatrics. Identification, evaluation, and management of children with autism spectrum disorders. Pediatrics. 2019;145(1):e20193447:1-64. https://doi.org/10. 1542/peds.2019-3447.

147. Iizuka C, Yamashita Y, Nagamitsu S, Yamashita T, Araki Y, Ohya T, et al. Comparison of the strengths and difficulties questionnaire (SDQ) scores between children with highfunctioning autism spectrum disorder (HFASD) and attention-deficit/hyperactivity disorder (AD/HD). Brain Dev. 2010;32(8):609-12. https://doi.org/10.1016/j.braindev. 2009.09.009.

148. Jacob S, Brune CW, Carter CS, Leventhal BL, Lord C, Cook EH Jr. Association of the oxytocin receptor gene (oxtr) in caucasian children and adolescents with autism. Neurosci Let. 2007;417(1):6-9. https://doi.org/10.1016/j.neulet. 2007.02.001.

149. Jahromi LB, Kasari CL, McCracken JT, Lee LS, Aman MG, McDougle CJ, et al. Positive effects of methylphenidate on social communication and self-regulation in children with pervasive developmental disorders and hyperactivity. J Autism Development Dis. 2009;39(3):395-404. https:// doi.org/10.1007/s10803-008-0636-9. J.

150. James S, Montgomery P, Williams K. Omega-3 fatty acids supplementation for autism spectrum disorders (ASD). Cochrane Database Syst Rev. 2011; https://doi.org/10. 1002/14651858.CD007992.pub2.

151. James S, Stevenson SW, Silove N, Williams K. Chelation for autism spectrum disorder (ASD). Coch Data Sys Rev. 2015;11(5):1-27,2015. 
152. Jensen PS, Buitelaar J, Pandina GJ, Binder C, Haas M. Management of psychiatric disorders in children and adolescents with atypical antipsychotics: a systematic review of published clinical trials. Eur J Child Adolesc Psychiatry. 2007;16(2):104-20.

153. Jesner OS, Aref-Adib M, Coren E. Risperidone for autism spectrum disorder. Cochrane Database Syst Rev. 2007; https://doi.org/10.1002/14651858.CD005040.pub2.

154. Ji NY, Findling RL. An update on pharmacotherapy for autism spectrum disorder in children and adolescents. Curr Opin Psychiatry. 2015;28(2):91-101. https://doi.org/10. 1097/YCO.0000000000000132.

155. Jia F, Wang B, Schan L, Xu Z, Staal WG, Du L. Core symptoms of autism improved after vitamin $D$ supplementation. Pediatrics. 2015;135(1):e196-e8.

156. Jobski K, Hofer J, Hoffmann F, Bachmann C. Use of psychotropicdrugsin patients with autism spectrum disorders: a systematic review. Acta Psych Scand. 2017;135(1):8-28. https://doi.org/10.1111/acps.12644.

157. Johnson CR, Turner KS, Foldes EL, Malow BA, Wiggs L. Comparison of sleep questionnaires in the assessment of sleep disturbances in children with autism spectrum disorders. Sleep Med. 2012;13:795-801.

158. Jones RA, Downing K, Rinehart NJJ, Barnett LM, May T, McGillivray JA, et al. Physical activity, sedentary behavior and their correlates in children with autism spectrum disorder: A systematic review. PLOS One. 2017;12(2):1-23. https://doi.org/10.1371/journal.pone.0172482.

159. Joshi G. Are there lessons to be learned from the prevailing patterns of psychotropic drug use in patients with autism spectrum disorder? Acta Psychiatr Scand. 2017;135(1):5-7. https://doi.org/10.1111/acps.12683.

160. Joshi G, Faraone SV, Wozniak J, Tarko L, Fried R, Galdo $\mathrm{M}$, et al. Symptom profile of ADHD in youth with highfunctioning autism spectrum disorder: a comparative study in psychiatrically referred populations. J Atten Disord. 2017;21(10):846-55. https://doi.org/10.1177/ 1087054714543368.

161. Joshi G, Biederman J, Petty C, Goldin RL, Furtak SL, Wozniak J. Examining the comorbidity of bipolar disorder and autism spectrum disorders: a large controlled analysis of phenotypic and familial correlates in a referred population of youth with bipolar I disorder with and without autism spectrum disorders. J Clin Psych. 2013;74(6):578-86. https://doi.org/10.4088/JCP.12m07392.

162. Jung S, Sainato DM. Teaching play skills to young children with autism. J Intellec Develop Disabil. 2013;38(1):74-90. https://doi.org/10.3109/13668250.2012.732220.

163. Kantzer A-K, Fernell E, Gillberg C, Miniscalco C. Autism in community pre-schoolers: developmental profiles. Res Develop Disabil. 2013;34(9):2900-8. https://doi.org/10. 1016/j.ridd.2013.06.016.

164. Kaplan G, McCracken JT. Psychopharmacology of autism spectrum disorders. Pediat Clin N Am. 2012;59(1):175-87. https://doi.org/10.1016/j.pcl.2011.10.005.

165. Karst JS, Van Hecke AV. Parent and family impact of autism spectrum disorders: a review and proposed model for intervention evaluation. Clin Child Fam Psych Rev. 2012;15(3):247-77. https://doi.org/10.1007/s10567-0120119-6.

166. Kasari C, Patterson S. Interventions addressing social impairment in autism. Cur Psych Rep. 2012;14(6):713-25. https://doi.org/10.1007/s11920-012-0317-4.

167. Kidwell KM, Van Dyk TR, Lundahl A, Nelson TD. Stimulant medications and sleep for youth with ADHD: A metaanalysis. Pediatrics. 2015;136(6):1144-53. https://doi.org/ 10.1542/peds.2015-1708.
168. King BH, Hollander E, Sikich L, McCracken JT, Scahill L, Bregman JD, et al. Lack of efficacy of citalopram in children with autism spectrum disorders and high levels of repetitive behavior. Arch Gen Psychiatry. 2009;66(6):583-90.

169. King BH. Fluoxetine and repetitive behaviors in children and adolescents with autism spectrum disorder. JAMA. 2019;322(16):1557-8.

170. Kirino E. Efficacy and tolerability of pharmacotherapy options for the treatment of irritability in autistic children. Clin Med Insights Pediatr. 2014;25(8):17-30.

171. Kleijer KTE, Schmeisser MJ, Krueger DD, Boeckers TM, Scheiffele P, Bourgeron T, et al. Neurobiology of autism gene products: towards pathogenesis and drug targets. Psychopharmacology (Berl.). 2014;231(6):1037-62.

172. Knight V, McKissickBR, Saunders A. A review of technologybased interventions to teach academic skills to students with autism spectrum disorder. J Autism Develop Disord. 2013. https://doi.org/10.1007/s10803-013-1814-y.

173. Kolevzon A, Mathewson KA, Hollander E. Selective serotonin reuptake inhibitors in autism: a review of efficacy and tolerability. JClin Psychiatry. 2006;67(3):407-14.

174. Kotagal S. Treatment of dyssomnias and parasomnias in childhood. Curr Treat Options Neurol. 2012;14(6):630-49.

175. Kotagal S, Broomall A. Sleep in children with autism spectrum disorder. Pediat Neurol. 2012;47(4):242-51. https:// doi.org/10.1016/j.pediatrneurol.2012.05.007.

176. Kruppa JA, Gossen A, Oberwelland Weiß E, Kohls G, Großheinrich N, Cholemkery H, et al. Neural modulation of social reinforcement learning by intranasal oxytocin in male adults with high-functioning autism spectrum disorder: a randomized trial. Neuropsychopharmacology. 2019;44(4):749-56. https://doi.org/10.1038/s41386-0180258-7.

177. Laugeson EA. Review: social skills groups may improve social competence in children and adolescents with autism spectrum disorder. Evidence-Based Mental Health. 2013;16(1):11. https://doi.org/10.1136/eb-2012-100985.

178. LeBlanc LA, Gillis JM. Behavioral interventions for children with autism spectrum disorders. Ped Clin N Am. 2012;59(1):147-64. https://doi.org/10.1016/j.pcl.2011.10. 006.

179. Lee DO, Ousley OY. Attention-deficit hyperactivity disorder symptoms in a clinic sample of children and adolescents with pervasive developmental disorders. J Child Adoles Psychopharmacol. 2006;16(6):737-46. https://doi.org/10. 1089/cap.2006.16.737.

180. Lee YJ, Oh SH, Park C, Hong M, Lee AR, Yoo HJ, et al. Advanced pharmacotherapy evidenced by pathogenesis of autism spectrum disorder. Clin Psychopharmacol Neurosci. 2014;12(1):19-30. https://doi.org/10.9758/cpn. 2014.12.1.19.

181. LeitnerY. The co-occurrence of autism and attention deficit hyperactivity disorder in children - What do we know? Front Hum Neurosci. 2014;8:268. https://doi.org/10.3389/ fnhum.2014.00268.

182. Lerner MD, Haque OS, Northrup EC, Lawer L, Bursztajn HJ. Emerging perspectives on adolescents and young adults with high-functioning autism spectrum disorders, violence, and criminal law. J Am Acad Psych Law. 2012;40(2):177-90.

183. Lerner MD, White SW, McPartland JC. Mechanisms of change in psychosocial interventions for autism spectrum disorders. Dialog Clin Neurosci. 2012;14(3):307-18.

184. Levy ML, Levy KM, Hoff D, Amar AP, Park MS, Conklin JM, et al. Vagus nerve stimulation therapy in patients with autism spectrum disorder and intractable epilepsy: results 
from the vagus nerve stimulation therapy patient outcome registry. J Neurosurg Pediatr. 2010;5(5):595-602.

185. Levy S. Complementary and alternative medicine among children recently diagnosed with Autistic Spectrum Disorder. J Dev Behav Pediatr. 2003;24:418-23.

186. Levy SE, Hyman SL. Complementary and alternative medicine treatments for children with autism spectrum disorders. Child Adolesc Psychiatry. 2015;24(1):117-43.

187. Leyfer OT, Folstein SE, Bacalman S, Davis NO, Dinh E, Morgan J, et al. Comorbid psychiatric disorders in children with autism: interview development and rates of disorders. J Autism Dev Disord. 2006;36(7):849-61. https://doi.org/ 10.1007/s10803-006-0123-0.

188. Ligsay A, Van Dijck A, Nguyen DV, Lozano R, Chen Y, Bickel ES, et al. A randomized double-blind, placebo-controlled trial of ganaxolone in children and adolescents with fragile X syndrome. J Neurodevelop Disord. 2017;9(1:26):1-13. https://doi.org/10.1186/s11689-017-9207-8.

189. Liu X, Hubbard JA, Fabes RA, Adam JB. Sleep disturbances and correlates of children with autism spectrum disorders. Child PsychiatryHum Dev. 2006;37:179-91.

190. LiuZ, Smith CB. Lithium: a promising treatment for fragileX syndrome. ACS Chem Neurosci. 2014;18(5):477-83.

191. Lofthouse N, Hendren R, Hurt E, Arnold LE, Butter E. A review of complementary and alternative treatments for autism spectrum disorders. Autism Res Treat. 2012;2012:870391. https://doi.org/10.1155/2012/870391.

192. Lord C, McGee JP. Educating children with autism. Washington, DC: National Academic Press; 2001.

193. Louis P. Does the human gut microbiota contribute to the etiology of autism spectrum disorders? Dig Dis Sci. 2012;57(8):1987-9. https://doi.org/10.1007/s10620-0122286- 1.

194. Mahdi F, SetiawatiY. Occupational therapy for children with attention deficit hyperactivity disorder: a literature review. JChild Adolesc Psychiatry. 2019;3(1):1-3.

195. Malone RP, Delaney MA, HymanSB, Cater JR.Ziprasidonein adolescents with autism: an open-label pilot study. JChild Adolesc Psychopharmacol. 2007;17(6):779-90.

196. Maloney A, Mick EO, Frazier J. Aripiprazole decreases irritabilityin 12 out of 14 youth with autism spectrum disorders. JChild Adolesc Psychopharmacol. 2014;24(6):357-9.

197. Malow BA, Byars K, Johnson K, Weiss S, Bernal P, Goldman SE, et al. A practice pathway for the identification, evaluation, and management of insomnia in children and adolescents with autism spectrum disorders. Pediatrics. 2012;130(Suppl 2):S106-24. https:// doi.org/10.1542/peds. 2012-0900I.

198. Martínez K, Martínez-García M, Marcos-Vidal L, Janssen J, Castellanos FX, Pretus C, et al. Sensory-to-cognitive systems integration is associated with clinical severity in autism spectrum disorder. J Am Acad Child Adoles Psych. 2019; electronic preprint:1-11, 2019. https://doi.org/10. 1016/j.jaac.2019.05.033.

199. Martinez-RagaJ,KnechtC, deAlvaro R.Profile ofguanfacine extended release and its potential in the treatment of attention-deficit hyperactivity disorder. Neuropsych Dis Treat. 2015;11:1359-70. https://doi.org/10.2147/ndt.s65735.

200. Masi G, MiloneA, Veltri S, Iuliano R, Pfanner C, Pisano S. Use of quetiapine in children and adolescents. Paediatr Drugs. 2015;17(2):125-40.

201. Matson JL, Cervantes PE. Commonly studied comorbid psychopathologies among persons with autism spectrum disorder. Res Dev Disabil. 2014;35(5):952-62. https://doi. org/10.1016/j.ridd.2014.02.012.
202. Matsuura H, Tateno K, Aou S. Dynamical properties of the two-process model for sleep-wake cycles in infantile autism. Cogn Neurodyn. 2008;2:221-8.

203. Mayer EA, Padua D, Tillisch K. Altered brain-gut axis in autism: comorbidity or causative mechanisms? Bioassays. 2014;36(10):933-9.

204. Mazahery H, Camargo Jr CA, Conlon C, Beck KL, Kruger MC, von Hurst PR. Vitamin D and Autism Spectrum Disorder: A Literature Review. Nutrients. 2016;8(4):236. https://doi. org/10.3390/nu8040236.

205. Mazurek MO, Dovgan K, Neumeyer AM, Malow BA. Course and predictors of sleep and co-occurring problems in children with autism spectrum disorder. J Autism Dev Disord. 2019;49(5):2101-15. https://doi.org/10.1007/ s10803-019-03894-5.

206. McCracken JT, Badashova KK, Posey DJ, Aman MG, Scahill L, TierneyE, et al. Positive effects of methylphenidate on hyperactivity are moderated by monoaminergic gene variants in children with autism spectrum disorders. Pharmacogenomics. 2014;14(3):295-302.

207. McCracken JT, McGough J, Shah B, Cronin P, Hong D, Aman MG, et al., and for Research Units on Pediatric Psychopharmacology Autism Network. Risperidone in children with autism and serious behavioral problems. New Eng J Med. 2002;347(5):314-21. https://doi.org/10. 1056/NEJMoa013171.

208. McDougle CJ, Scahill L, McCracken JT, Aman MG, Tierney E, Arnold LE, et al. Research Units on Pediatric Psychopharmacology (RUPP) Autism Network. Background and rationale for an initial controlled study of risperidone. Child Adolesc Psychiatr Clin NAm. 2000;9(1):201-24.

209. McEachin JJ, Smith T, Lovaas OI. Long-term outcome for children with autism who received early intensive behavioral treatment. Am J Ment Retard. 1993;97(4):359-72.

210. McPheeters ML, Warren Z, Sathe N, Bruzek JL, Krishnaswami S, Jerome RN, et al. A systematic review of medical treatments for children with autism spectrum disorders. Pediatrics. 2011;127(5):e1312-e21.

211. Mesibov GB, Shea V, Schopler E. The TEACCH approach to autism spectrum disorders. Issues in clinical child psychology. NewYork: Springer; 2004.

212. Micoulaud-Franchi JA, Geoffroy PA, Fond G, Lopez R, Bioulac S, Philip P. EEG neurofeedback treatments in children with ADHD: An updated meta-analysis of randomized controlled trials. Front Hum Neurosci. 2014; https://doi.org/ 10.3389/fnhum.2014.00906.

213. Mikami AY, Jia M, Na JJ. Social skills training. Child Adoles Psych Clin N Am. 2014;23(4):775-88. https://doi.org/10. 1016/j.chc.2014.05.007.

214. Minshawi NF, Wink LK, Shaffer R, Plawecki MH, Posey DJ, Liu $\mathrm{H}$, et al. A randomized, placebo-controlled trial of d-cycloserine for the enhancement of social skills training in autism spectrum disorders. Mol Autism. 2016;7:2. https://doi.org/10.1186/s13229-015-0062-8.

215. Modi ME, Inoue K, Barrett CE, Kittelberger KA, Smith DG, Landgraf R, et al. Melanocortin receptor agonists facilitate oxytocin-dependent partner preference formation in the prairie vole. Neuropsychopharmacology. 2015;40:1856-65.

216. Möhler $H$. The legacy of the benzodiazepine receptor: from flumazenil to enhancing cognition in Down syndrome and social interaction in autism. Adv Pharmacol. 2015;72:1-36. https://doi.org/10.1016/bs.apha.2014.10.008.

217. Molnar-Szakacs I, Heaton P. Music: a unique window into the world of autism. Ann New York Acad Sci. 2012;1252:318-24. https://doi.org/10.1111/j.1749-6632. 2012.06465.x. 
218. Molteni M, Nobile M, Cattaneo D, Radice S, Clementi E. Potential benefits and limits of psychopharmacological therapies in pervasive developmental disorders. CCP. 2014;9(4):365-76.

219. Montoya A, Colom F, Ferrin M. Is psychoeducation for parents and teachers of children and adolescents with ADHD efficacious? A systematic literature review. Eur psychiatr. 2011;26(3):166-75. https://doi.org/10.1016/j. eurpsy.2010.10.005.

220. Moyal WN, Lord C, Walkup JT. Quality of life in children and adolescents with autism spectrum disorders: what is known about the effects of pharmacotherapy? Paediatr Drugs. 2014;16(2):123-8.

221. Myers SM, Plauché Johnson C, and the Council on Children With Disabilities. Management of children with autism spectrum disorders. Pediatrics. 2007;120(5):1162-82. https://doi.org/10.1542/peds.2007-2362.

222. Nadeau J, Sulkowski ML, Ung D, Wood JJ, Lewin AB, Murphy TK, et al. Treatment of comorbid anxiety and autism spectrum disorders. Neuropsychiatry (london). 2011;1(6):567-78.

223. Newcorn JH, Halperin JM, Jensen PS, Abikoff HB, Arnold LE, CantwellDP, etal. Symptom profiles in children with ADHD: Effects of comorbidity and gender. J Am Acad Child Adoles Psych. 2001;40(2):137-46.

224. Niederhofer H. Efficacy of Duloxetine and Agomelatine does not exceed that of other antidepressants in patients with autistic disorder: preliminaryresultsin 3 patients. Prim Care Companion Cns Disord. 2011;13(1):PCC.10I0138.

225. Nijmeijer JS, Arias-Vásquez A, Rommelse NNJ, Altink ME, Anney RJL, Asherson P, et al. Identifying loci for the overlap between attention-deficit/hyperactivity disorder and autism spectrum disorder using a genome-wide QTL linkage approach. J Am Acad Child Adoles Psych. 2010;49(7):675-85.

226. Novack MN, Hong E, Dixon DR, Granpeesheh D. An evaluation of a mobile application designed to teach receptive language skills to children with autism spectrum disorder. BehavAnalysis Practice. 2018;12(1):66-77.https://doi.org/ 10.1007/s40617-018-00312-7.

227. Ojemann LM, Ojemann GA, Dodrill CB, Crawford CA, Holmes MD, Dudley DL. Language disturbances as side effects of topiramate and zonisamide therapy. Epilepsy Behav. 2001;2(6):579-84. https://doi.org/10.1006/ebeh. 2001.0285.

228. Ooi YP, Weng S-J, Kossowsky J, Gerger H, Sung M. Oxytocin and autism spectrum disorders: a systematic review and meta-analysis of randomized controlled trials. Pharmacopsychiatry. 2017;50(1):5-13. https://doi.org/10.1055/s0042-109400.

229. Orinstein AJ, Helt M, Troyb E, Tyson KE, Barton ML, Eigsti I-M, et al. Intervention history of children and adolescents with high-functioning autism and optimal outcomes. JDev Behav Pediatr. 2014;35(4):247-56. https://doi.org/10. 1097/DBP.0000000000000037.

230. Owada K, Okada T, Munesue T, Kuroda M, Fujioka T, Uno Y, et al. Quantitative facial expression analysis revealed the efficacy and time course of oxytocin in autism. Brain. 2019;142(7):2127-36. https://doi.org/10.1093/ brain/awz126.

231. Owen R, Linmarie Sikich RNM, Corey-Lisle P, Manos G, McQuade RD, Carson $\mathrm{WH}$, et al. Aripiprazole in the treatment of irritability in children and adolescents with autistic disorder. Pediatrics. 2009;124(6):1533-40. https:// doi.org/10.1542/peds.2008-3782.

232. Owley T, Walton L, Salt J, Guter S, Winnega M, Leventhal BL, et al. An open-label trial of excitalopram in pervasive de- velopmental disorders. JAm Acad Child Adolesc Psychiatry. 2005;44(4):343-8.

233. Owley T, Salt J, Guter S, Grieve A, Walton L, Ayuyao N, et al. A prospective, open-label trial of memantine in the treatment of cognitive, behavioral, and memory dysfunction in pervasive developmental disorders. J Child Adolesc Psychopharmacol. 2006;16(5):517-24.

234. Pagel JF, Parnes BL. Medications for the treatment of sleep disorders: an overview. Prim Care Companion J Clin Psychiatry. 2001;3(3):118-25.

235. Parker KJ, Oztan O, Libove RA, Mohsin DS, Karhson $\mathrm{N}$, Sumiyoshi RD, et al. A randomized placebo-controlled pilot trial shows that intranasal vasopressin improves social deficits in children with autism. Sci Transl Med. 2019;11(491):eaau7356. https://doi.org/10.1126/ scitranslmed.aau7356.

236. Patra S, Nebhinani N, Viswanathan A, Kirubakaran R. Atomoxetine for attention deficit hyperactivity disorder in children and adolescents with autism: A systematic review and meta-analysis. Autism Res. 2019;12(4):542-52.https:// doi.org/10.1002/aur.2059.

237. Patrick RP, Ames BN. Vitamin D hormone regulates serotonin synthesis. Part 1: relevance for autism. FASEB J. 2014;28(6):2398-413.

238. Pearson DA, Santos CW, Aman MG, Arnold LE, Casat $\mathrm{CD}$, Mansour R, et al. Effects of extended release methylphenidate treatment on ratings of attention-deficit/ hyperactivity disorder (adhd) and associated behavior in children with autism spectrum disorders and ADHD symptoms. J Child Adoles Psychopharmacol. 2013;23(5):337-51. https://doi.org/10.1089/cap.2012.0096.

239. Pelsser LM, Frankena K, Toorman J, Rodrigues Pereira R. Diet and ADHD, reviewing the evidence: A systematic review of meta-analyses of double-blind placebo-controlled trials evaluating the efficacy of diet interventions on the behavior of children with ADHD. PLOS ONE. 2017;12(1):e0169277. https://doi.org/10.1371/journal. pone.0169277.

240. Penagarikano O. New therapeutic options for autism spectrum disorder: Experimental evidences. Exp Neurobiol. 2015;24(4):301-11. https://doi.org/10.5607/en.2015.24.4. 301.

241. Politte LC, Henry CA, McDougle CJ. Psychopharmacological interventions in autism spectrum disorder. Harv Rev Psychiatry. 2014;22(2):76-92. https://doi.org/10.1097/ HRP.0000000000000030.

242. Posey DI, Litwiller M, Koburn A, McDougle CJ. Paroxetine in autism. J Am Acad Child Adolesc Psychiatry. 1999;38(2):111-2.

243. Posey DJ, Guenin KD, Kohn AE, Swiezy NB, McDougle CJ. A naturalistic open-label study of mirtazapine in autistic and other pervasive developmental disorders. J Child Adolesc Psychopharmacol. 2001;11:267-77.

244. Posey DJ, Wiegand RE, Wilkerson J, Maynard M, Stigler KA, McDougle CJJ. Open-label atomoxetine for attention-deficit/hyperactivity disorder symptoms associated with high-functioning pervasive developmental disorders. JChild Adolesc Psychopharmacol. 2006;16(5):599-610.

245. Poustka L, Bender F, Bock M, Bölte S, Möhler E, Banaschewski $\mathrm{T}$, et al. Temperament und soziale Reaktiviät bei Autismus-Spektrum-Störungen und ADHS [Personality and social responsiveness in autism spectrum disorders and attention deficit/hyperactivity disorder]. Z Kinder Jugendpsychiatr Psychother. 2011;39:133-41. https://doi. org/10.1024/1422-4917/a000099.

246. Poustka L, Brandeis D, Hohmann M, Bölte S, Banaschewski T. Neurobiologically based interventions for autism spec- 
trum disorders - rationale neurobiology based interventions for autism spectrum disorders - rationale and new directions. RNN. 2014;32(1):197-212.

247. Premoli M, Aria F, Bonini SA, Maccarinelli G, Gianoncelli A, Pina SD, et al. Cannabidiol: recent advances and new insights for neuropsychiatric disorders treatment. Life. 2019;224:120-7.

248. Preti A, Melis M, Siddi S, Vellante M, Doneddu G, Fadda R. Oxytocin and autism: a systematic review of randomized controlled trials. J Child Adolesc Psychopharmacol. 2014;24(2):54-68.

249. Rajapakse T, Pringsheim T. Pharmacotherapeutics of Tourette syndrome and stereotypies in autism. Semin Pediatr Neurol. 2010;17(4):254-60.

250. Ramdoss S, Machalicek W, Rispoli M, Mulloy A, Lang R, O'Reilly M. Computer-based interventions to improve social and emotional skills in individuals with autism spectrum disorders: a systematic review. Dev Neurorehabil. 2012;15(2):119-35. https://doi.org/10.3109/17518423. 2011.651655.

251. Rao PA, Landa RJ. Association between severity of behavioral phenotype and comorbid attention deficit hyperactivity disorder symptoms in children with autism spectrum disorders. Autism. 2013;18(3):272-80. https://doi.org/10. $1177 / 1362361312470494$.

252. Razoki B. Neurofeedback versus psychostimulants in the treatment of children and adolescents with attentiondeficit/hyperactivity disorder: a systematic review. Neuropsych Dis Treat. 2018;14:2905-13. https://doi.org/10. $2147 /$ ndt.s178839.

253. Reddihough DS, Marraffa C, Mouti A, O'Sullivan M, Lee $\mathrm{KJ}$, Orsini F, et al. Effect of fluoxetine on obsessivecompulsive behaviors in children and adolescents with autism spectrum disorders. A randomized clinical trial. JAMA. 2019;322(16):1561-9.

254. Reichow B, Barton EE, Boyd BA, Hume K. Early intensive behavioral intervention (EIBI) for young children with autism spectrum disorders (ASD). Cochrane Database Sys Rev. 2012;10(CD009260):1-63. https://doi.org/10.1002/ 14651858.CD009260.pub2.

255. Research Units on Pediatric Psychopharmacology (RUPP) Autism Network. A randomized controlled crossover trial of methylphenidate in pervasive developmental disorders with hyperactivity. Arch Gen Psych. 2005;62:1266-1274.

256. Reynolds AM, Soke GN, Sabourin KR, Hepburn S, Katz T, Wiggins LD, et al. Sleep problems in 2- to 5-year-olds with autism spectrum disorder and other developmental delays. Pediatrics. 2019;14(3):pii:e20180492. https://doi.org/10. 1542/peds.2018-0492.

257. Rezaei V, Mohammadi MR, Ghanizadeh A, Sahraian A, Tabrizi M, Rezzadeh SA, et al. Double-blind, placebocontrolled trial of risperidone plus topiramate in children with autistic disorder. Prog Neuropsychopharmacol Biol Psychiatry. 2010;34(7):1269-72.

258. Richardson E, Seibert T, Uli NK. Growth perturbations from stimulant medications and inhaled corticosteroids. Transl Pediatr. 2017;6(4):237-47. https://doi.org/10.21037/tp. 2017.09.14.

259. Ridderinkhof A, de Bruin EI, Blom R, Bögels SM. Mindfulness-based program for children with autism spectrum disorder and their parents: Direct and long-term improvements. Mindfulness. 2018;9(3):773-91. https://doi.org/10. 1007/s12671-017-0815-x.

260. Ringman JM, Jankovic J. Occurrence of tics in Asperger's syndrome and autistic disorder. J Child Neurol. 2000;21(8):1081-109.
261. Robinson SJ. Childhood epilepsy and autism spectrum disorders: psychiatric problems, phenotypic expression, and anticonvulsants. Neuropsychol Rev. 2012;22(3):271-9. https://doi.org/10.1007/s11065-012-9212-3.

262. Roessner V, Schoenefeld K, Buse J, Wanderer S, Rothenberger A. Therapie der Tic-Störungen [Therapy of tic disorders]. ZKinder Jugendpsychiatr. 2012;40(4):217-37.

263. Rogers SJ, Vismara LA. Evidence-based comprehensive treatments for early autism. J Clin Child Adolesc Psychol. 2008;37(1):8-38.

264. Rommelse NNJ, AltinkME, FliersEA, Martin NC, Buschgens CJM, Hartman CA, et al. Comorbid problems in ADHD: degree of association, shared endophenotypes, and formation of distinct subtypes. implications for a future DSM. J Abnorm Child Psych. 2009;37(6):793-804. https://doi. org/10.1007/s10802-009-9312-6.

265. Ronald A, Simonoff E, Kuntsi J, Asherson P, Plomin R. Evidence for overlapping genetic influences on autistic and ADHD behaviours in a community twin sample. J Child Psychol Psychiatry. 2008;49(5):535-42. https://doi.org/10. 1111/j.1469-7610.2007.01857.x.

266. Ronald A, Larsson H, Anckarsäter H, Lichtenstein P. Symptoms of autism and ADHD: a Swedish twin study examining their overlap. J Abnorm Psychol. 2014; https://doi.org/10. 1037/a0036088.

267. Rossignol DA, Frye RE. Melatonin in autism spectrum disorders. CCP. 2014;9(4):326-34.

268. Saunders DC. Mindfulness-based ADHD treatmentfor children: a pilot feasibility study. J Acad Child Adoles Psych. 2019;58(Suppl 10):312. American Academy of Child \& Adolescent Psychiatry (AACAP) 66th Annual Meeting.

269. Scahill L, Aman MG, McDougle CJ, McCracken JT, Tierney E, Dziura J, et al. A prospective open trial of guanfacine in children with pervasive developmental disorders. J Child Adolesc Psychopharmacol. 2006;16(5):589-98.

270. Scahill L, McCracken JT, King BH, Rockhill C, Shah B, Politte $\mathrm{L}$, et al. Extended release guanfacine for hyperactivity in children with autism spectrum disorder. Am J Psychiatry. 2015;172(12):1197-206. https://doi.org/10.1176/appi.ajp. 2015.15010055 .

271. Scahill L, McDougle CJ, Williams SK, Dimitropoulos A, Aman MG, McCracken JT, et al. Children's yalebrown obsessive compulsive scale modified for pervasive developmental disorders. J Am Acad Child Adoles Psych. 2006;45(9):1114-23. https://doi.org/10.1097/01. chi.0000220854.79144.e7.

272. ScheltemaBeduinA, deHaanL.Off-label secondgeneration antipsychotics for impulse regulation disorders: a review. Psychopharmacol Bull. 2010;43(3):45-81.

273. Schmeck K. Antipsychotika im Kindes- und Jugendalter: pro und contra [Pros and cons of antipsychotics in children and adolescents]. Prax Schweiz Rundsch Med. 2015;104(16):859-64.

274. Schneider BN, Enenbach M. Managing the risks of ADHD treatments. Current Psych Rep. 2014;16(10):479. https:// doi.org/10.1007/s11920-014-0479-3.

275. Schreibman L. Intensive behavioral/psychoeducational treatments for autism: research needs and future direction. JAutism Dev Disord. 2000;30(5):373-8.

276. Schur SB, Sikich L, Findling RL, Malone RP, Crismon ML, Derivan A, et al. Treatment recommendations for the use of antipsychotics for aggressive youth (TRAAY). Part ii. A review. J Am Acad Child Adolesc Psychiatry. 2003;43(2):132-44. https://doi.org/10.1097/01.CHI. $0000037017.34553 .2 \mathrm{E}$.

277. Scott J, Etain B, Bellivier F. Can an integrated science approach to precision medicine research improve 
lithium treatment in bipolar disorders? Front Psychiatry. 2018;9(360):1-10.

278. Scott LJ, Dhillon S. Risperidone: a review of its use in the treatment of irritability associated with autistic disorder in children and adolescents. Paediatr Drugs. 2007;9(5):343-54.

279. Scotto Rosato N, Correll CU, Pappadopulos E, Chait A, Crystal S, Jensen PS on behalf of the Treatment of Maladaptive Aggressive in Youth Steering Committee. Treatment of maladaptive aggression in youth: CERT guidelines II. treatments and ongoing management. Pediatrics. 2012;129(6):e1577-586. https://doi.org/10.1542/ peds.2010-1361.

280. Silva GE, Goodwin JL, Vana KD, Vasquez MM, Wilcox PG, Quan SF. Restless legs syndrome, sleep, and quality of life among adolescents and young adults. J Clin Sleep Med. 2014;10(7):779-86. https://doi.org/10.5664/jcsm.3872.

281. Simonoff E, Pickles A, Charman T, Chandler S, Loucas T, Baird G. Psychiatric disorders in children with autism spectrum disorders: prevalence, comorbidity, and associated factors in a population-derived sample. J Am Acad Child Adolesc Psychiatry. 2008;47(8):921-9. https://doi.org/10. 1097/CHI.0b013e318179964f.

282. Simonoff E, Taylor E, Baird G, Bernard S, Chadwick O, Liang $\mathrm{H}$, et al. Randomized controlled double-blind trial of optimal dose methylphenidate in children and adolescents with severe attention deficit hyperactivity disorder and intellectual disability. J Child Psychol Psychiatry. 2013;54(5):527-35. https://doi.org/10.1111/j.1469-7610. 2012.02569.x.

283. sleepjunkie. The ultimate guide to helping children with autism sleep soundly at night. https://www.sleepjunkie. org/autism-and-sleep/, 2019. Accessed: 17 Jun 2021.

284. Solanto MV. Neuropsychopharmacological mechanisms of stimulant drug action in attention-deficit hyperactivity disorder: a review and integration. Behav Brain Res. 1998;98(1):127-52.

285. Southammakosane C, Schmitz K. Pediatric psychopharmacology for treatment of ADHD, depression, and anxiety. Pediatrics. 2015;136(2):351-9. https://doi.org/10.1542/ peds.2014-1581.

286. Sowa M, Meulenbroek K. Effects of physical exercise on autism spectrum disorders: a meta-analysis. Res Autrism Spectr Disord. 2012;6(1):46-57. https://doi.org/10.1016/j. rasd.2011.09.001.

287. Spence SJ, Schneider MT. The role of epilepsy and epileptiform EEGs in autism spectrum disorders. Pediatr Res. 2009;65:599-606.

288. Spencer D, Marchall J, Post B, Kulakodlu M, Newschaffer C, Dennen T, et al. Psychotropic medication use and polypharmacy in children with autism spectrum disorders. Pediatrics. 2013;132(5):833-40.

289. Srinivasan SM, Bhat AN. A review of "music and movement" therapies for children with autism: embodied interventions for multisystem development. Front Integrat Neurosci. 2013;7(22):1-15. https://doi.org/10.3389/fnint. 2013.00022.

290. Stachnik JM, Nunn-Thompson C. Use of atypical antipsychotics in the treatment of autistic disorder. Ann Pharmacother. 2007;41(4):626-34.

291. Stavrakaki C, Antochi R, Emery PC. Olanzapine in the treatment of pervasive developmental disorders: a case series analysis. JPN. 2004;29(1):57-60.

292. Steingard RJ, Zimnitzky B, DeMaso DR, Bauman ML, Bucci JP. Sertraline treatment of transition-associated anxiety and agitation in children with autistic disorder. J Child Adolesc Psychopharmacol. 1997;7(1):9-15.
293. Stevenson J, Buitelaar J, Cortese S, Ferrin M, Konofal E, Lecendreux M, et al., and on behalf of the European ADHD Guidelines Group. Research review: The role of diet in the treatment of attention-deficit/hyperactivity disorder - an appraisal of the evidence on efficacy and recommendations on the design of future studies. J Child Psychol Psychiat. 2014;55(5):416-27. https://doi.org/0.1111/jcpp.12215.

294. Stigler KA. Psychopharmacologic management of serious behavioral disturbancein ASD. Child Adolesc Psychiatr Clin NAm. 2014;23(1):73-82.

295. Stigler KA, McDougle CJ. Pharmacotherapy of irritability in pervasive developmental disorders. Child Adolesc Psychiatr Clin NAm. 2008;17(4):739-52.

296. Sturman N, Deckx L, van Driel ML. Methylphenidate for children and adolescents with autism spectrum disorder. Cochrane Database Sys Rev. 2017;11(Cd011144):1-98. https://doi.org/10.1002/14651858.CD011144.pub2.

297. Sung M, Chin CH, Lim CG, Liew HSA, Lim CS, Kashala E, et al. What's in the pipeline? Drugs in development for autism spectrum disorder. NDT. 2014;10:371-81.

298. Tarrant N, Roy M, Deb S, Odedra S, Retzer A, Roy A. The effectiveness of methylphenidate in the management of attention deficit hyperactivity disorder (ADHD) in people with intellectual disabilities: A systematic review. Res Development Disabil. 2018;83:217-232. https://doi.org/ 10.1016/j.ridd.2018.08.017.

299. Tonge BJ, Bull K, Brereton A, Wilson R. A review of evidence-based early intervention for behavioural problems in children with autism spectrum disorder: the core components of effective programs, child-focused interventions and comprehensive treatment models. Curr Opin Psychiatry. 2014;27(2):158-65.

300. Torres N, Martins D, Ant'onio JS, Prata D, Veríssimo M. How do hypothalamic nonapeptides shape youth's sociality? a systematic review on oxytocin, vasopressin and human socio-emotional development. Neurosci Biobehav Rev. 2018;90:309-31. https://doi.org/10.1016/j.neubiorev. 2018.05.004.

301. Torres-Aleman I. Toward a comprehensive neurobiology of IGF-I. Devel Neurobio. 2010;70(5):384-96. https://doi.org/ 10.1002/dneu.20778.

302. Toscano CVA, Carvalho HM, Ferreira JP. Exercise effects for children with autism spectrum disorder: metabolic health, autistic traits, and quality of life. Percept Mot Skills. 2018;125(1):126-46. https://doi.org/10.1177/ 0031512517743823.

303. Tuchman R, Alessandri M, Cuccaro M. Autism spectrum disorder and epilepsy: Moving towards a comprehensive approach to treatment. Brain Dev. 2010;32:719-30.

304. Tye C, Runicles AK, Whitehouse AJO, Alvares GA. Characterizing the interplay between autism spectrum disorder and comorbid medical conditions: an integrative review. Front Psychiatry. 2019; https://doi.org/10.3389/ fpsyt.2018.00751.

305. Uren J, Richdale AL, Cotton SM, Whitehouse AJO. Sleep problems and anxiety from 2 to 8 years and the influence of autistic traits: a longitudinal study. Eur Child. 2019;28(8):1117-27. https://doi.org/10.1007/s00787-01901275-y.

306. van Ijzendoorn MH, Bakermans-Kranenburg MJ. The role of oxytocin in parenting and as augmentative pharmacotherapy; critical issues and bold conjectures. J Neuroendocrinology. 2015;27(1):1-8. https://doi.org/10.1111/jne. 12355.

307. Vanucchi G, Masi G, Toni C, Dell'Osso L, Erfurth A, Perugi G. Bipolar disorder in adults with Asperger's Syndrome: a systematic review. JAffect Disord. 2014;168:151-60. 
308. Veatch OJ, Maxwell-Horn AC, Malow BA. Sleep in autism spectrum disorders. Curr Sleep Medicine Rep. 2015;1(2):131-40.

309. Veenstra-VanderWeele J, Muller CL, Iwamoto H, Sauer JE, Owens WA, ShahCR, et al. Autism gene variant causes hyperserotonemia, serotonin receptor hypersensitivity, social impairment and repetitive behavior. Proceed Nat Acad Sci. 2012;109(14):5469-74. https://doi.org/10.1073/pnas. 1112345109.

310. Venkateswaran S, Shevell M. The case against routine encephalography in specific language impairment. Pediatrics. 2008;122:e911-e6.

311. Wang L, Conion MA, Christophersen CT, Sorich MJ, Angley MT. Gastrointestinal microbiota and metabolite biomarkers in children with autism spectrum disorders. Biomarkers Med. 2014;8(3):331-44.

312. Ward F, Tharian P, Roy S, Deb M, Unwin GL. Efficacy of beta blockers in the management of problem behaviours in people with intellectual disabilities: a systematic review. Res Dev Disabil. 2013;34(12):4293-303.

313. Watanabe T, Kuroda M, Kuwabara H, Aoki Y, Iwashiro N, Tatsunobu N, et al. Clinical and neural effects of six-week administration of oxytocin on core symptoms of autism. Brain. 2015;138:3400-12.

314. Weiskop S, Richdale A, Matthews J. Behavioural treatment to reduce sleep problems in children with autism or fragilex syndrome. Dev Med Child Neurol. 2005;47(2):94-104.

315. Weissman JR, Kelley RI, Bauman ML, Cohen BH, Murray KF, Mitchell RL, et al. Mitochondrial disease in autism spectrum disorder patients: a cohort analysis. PLoS ONE. 2008;3(11):e3815.

316. Whitehouse AJ. Complementary and alternative medicine for autism spectrum disorders: Rationale, safety and efficacy. J Paediatrics Child Health. 2013. https://doi.org/10. $1111 / j p c .12242$.

317. Wiggs L, Stores G. Sleep patterns and sleep disorders in children with autistic spectrum disorders: insights using parent report and actigraphy. Dev Med Child Neurol. 2004;46:372-80.

318. Wijnhoven LAMW, Niels-Kessels H, Creemers DHM, Vermulst AA, Otten R, Engels RCME. Prevalence of comorbid depressive symptoms and suicidal ideation in children with autism spectrum disorder and elevated anxiety symptoms. JChild Adolesc Ment Health. 2019;31(1):77-84. https:// doi. org/10.2989/17280583.2019.1608830.

319. Williams K, Brignell A, Randall M, SiloveP,Hazell N. Selective serotonin reuptake inhibitors (SSRIs) for autism spectrum disorders (ASD). Cochrane DatabaseSystRev. 2013; https:// doi.org/10.1002/14651858.CD004677.pub3.

320. World Health Organization. ICD-11 for mortality and morbidity statistics (Version : 04/2019). https://icd.who. int/browse11/l-m/en, 2019. Accessed: 17 Jun 2021

321. Yamasue H, Domes G. Behav Pharmacol Neuropep: Oxytocin, volume 35 of Current Topics in Behavioral Neurosciences, chapter Oxytocin and Autism Spectrum Disorders, pages 449-465. Springer, 2019. https://doi.org/10. $1007 / 7854 \_201724$.

322. Yatawara CJ, Einfeld SL, Hickie IB, Davenport TA, Guastella AJ. The effect of oxytocin nasal spray on social interaction deficits observed in young children with autism: a randomized clinical crossover trial. Mol Psychiatry. 2016;21(9):1225-31.https://doi.org/10.1038/mp.2015. 162.

323. ZaboskiBA, StorchEA.Comorbid autism spectrum disorder and anxiety disorders: a brief review. Future Neurol. 2018;13(1):31-7. https://doi.org/10.2217/fnl-2017-0030.

324. Zahid S, Upthegrove R. Suicidality in autistic spectrum disorders. Crisis. 2017;38(4):237-46. https://doi.org/10. 1027/0227-5910/a000458.

325. Zimmer M, Desch L. Sensory integration therapies for children with developmental and behavioral disorders. Pediatrics. 2012;129(6):1186-9. https://doi.org/10.1542/ peds.2012-0876.

326. Zuddas A, Zanni R, Usala T. Second generation antipsychotics (SGAs) for non-psychotic disorders in children and adolescents: a review of the randomized controlled studies. Eur Neuropsychopharmacol. 2011;21(8):600-20.

Publisher's Note Springer Nature remains neutral with regard to jurisdictional claims in published maps and institutional affiliations. 